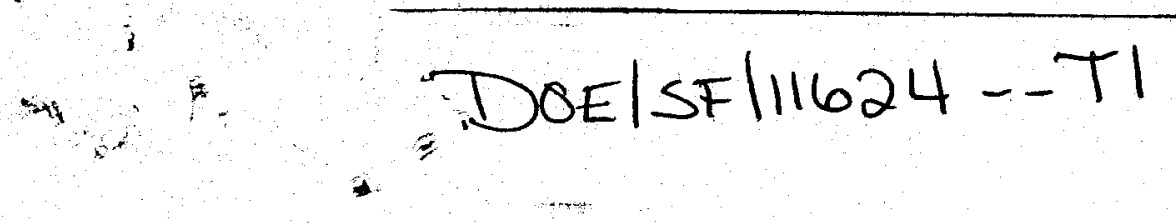

\title{
DRILLING, COMPLETION, AND TESTING OF GEOTHERMAL WELLS CD-1 AND CD-2 \\ CALIENTE, NEVADA
} $N V-81-001$
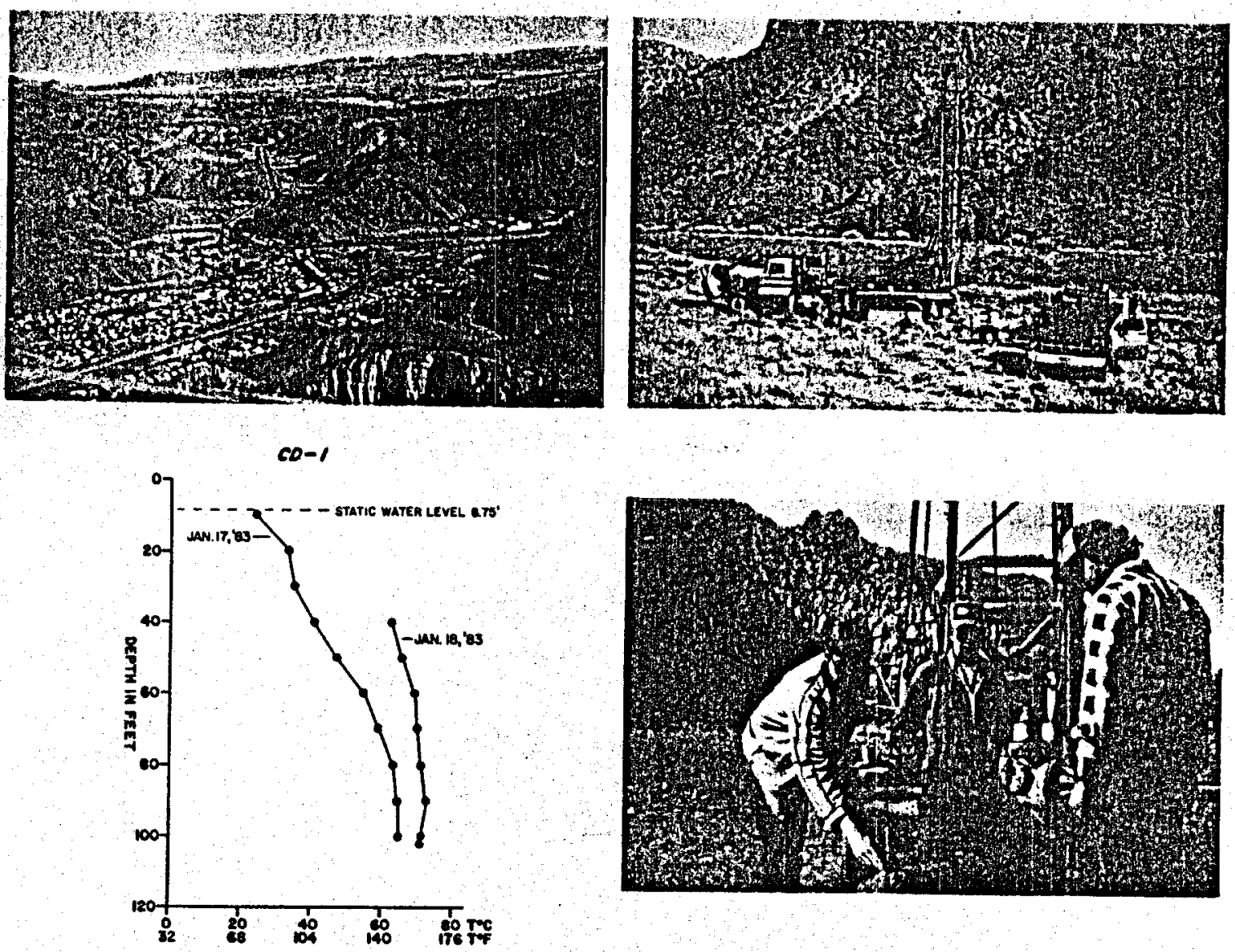

WORK PERFORMED UNDER U.S. DEPARTMENT OF ENERGY CONTRACT NO. DE-FGO3-81SF11624

PREPARED BY:

The City of Caliente and

Thomas Fiynn

Consulting Geologist

REMCO

Earth Sciences Division

P.O. Box 5011

Reno, Nevada 89513
DOE/SF/11624--T1

DE86 000401 


\section{DISCLAIMER}

This report was prepared as an account of work sponsored by an agency of the United States Government. Neither the United States Government nor any agency Thereof, nor any of their employees, makes any warranty, express or implied, or assumes any legal liability or responsibility for the accuracy, completeness, or usefulness of any information, apparatus, product, or process disclosed, or represents that its use would not infringe privately owned rights. Reference herein to any specific commercial product, process, or service by trade name, trademark, manufacturer, or otherwise does not necessarily constitute or imply its endorsement, recommendation, or favoring by the United States Government or any agency thereof. The views and opinions of authors expressed herein do not necessarily state or reflect those of the United States Government or any agency thereof. 


\section{DISCLAIMER}

Portions of this document may be illegible in electronic image products. Images are produced from the best available original document. 
3

Introduction - Scope of Program Page Executive Sumary . . $\ldots \ldots \ldots$. . vi Acknowledgements. . . ...... . . xi1

Drilling Report

Introduction . . . . . . . . . . . . 1

Drill Site Selection ......... 1

Drilling Specifications and Monitoring Techniques. . .

Summary of Drilling Activities, Holes CD-1, CD-2 .....,

Analysis of Drill Hole Data, CD-1, CD-2. . ....... 12

Well Completion and Pump Tests. ............... 15

Introduction .................. 15

Pumping and Measuring Specifications ...........17

Summary of Daily Activities. .............. 19

$\mathrm{CD}-1$ Aquifer Tests ................21

Findings. . .................21

Recommendations .................21

Aquifer Test....................21

CD-1 Step Drawdown Evaluation. . . . . ... 21

CD-1 Constant Rate Evaluation. .......... 22

Observation Well Results ............24

Conclusions ........ 27

Temperature Gradient Measurements in Observation Wells .... 30

Fluid Geochemistry. ................... 34

Introduction ..................... 34

Sampling and Analytical Techniques ............ 39

Analytical Results ................. 39

Data Interpretation. .................4 40

Conclusions and Recommendations

References.

Append ix. 


\section{LIST OF FIGURES}

Figure 1: OrIgInal Test Well Dr111 Site

Page

Recommendat fons . . . . . . . . . . . . 2

Figure 2: F-Wallis-1 Geothermal Well

Temperature-Depth Profile ............. . 4

Figure 3: J-Wilkens Geothermal Well

Temperature-Depth Profile ............... 5

Figure 4: Temperature-Depth Profiles of

CD-1, Jan. 15-Jan. 16, $1983 \ldots . . . . . . . . . .8$

Figure 5: Temperature-Depth Profiles of

CD-1, Jan. 17-Jan. 18, 1983 ........... 9

Figure 6: Temperature-Depth Profile of

CD-2, Jan. 21, $1983 \ldots . . . . . . . . . . . .11$

Figure 7: Lithologic Logs of Drill Holes

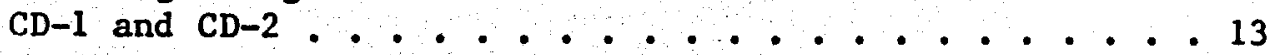

Figure 8: Well Completion of $\mathrm{CD}-1 \ldots \ldots \ldots$

Figure 9: Step Drawdown Tests - (Logarithmic)

time scale....................... 23

Figure 10: CD-1, 26 Hour Pump Test ................ 25

Figure 11: A. CD-1, 72 Hour Pump Test

B. $C D-1,48$ Hour Pump Test. ............ 26

Figure 12: Water Level Measurements in Observation Wells $\mathrm{JW}$ and $\mathrm{CD}-2,2 / 15 / 83$ through $2 / 25 / 83, \ldots \ldots . \ldots . . ., 28$ 


\section{(FICURES cont Inued)}

Figure 13: Temperature Gradient Measurements in Observation

Page

We11 CD-2, 2/15/83 through $2 / 25 / 83$. . . . . . . 31

Figure 14: Temperature Gradlent Measurements in Observation

Well JW, $2 / 15 / 83$ through $2 / 25 / 83$. . . . . . . . 32

Figure 15: Piper Plot of Caliente Water Samples

Trexler and others $(1980 \mathrm{a}) . . . . . . . . . .36$

Figure 16: Stable-1ight Isotope Ratios of Thermal

and Non-thermal Waters in Caliente

(Trexler and others, 1980b) . . . . . . . . 38

Figure 17: Piper Plot Comparative Analyses of

Thermal Water Collected During Pump Test

of CD-1 and Data from Trexler and others,

$1980 \mathrm{a}$. . . . . . . . . . . . 4 42

Figure 18: Chemical Variations of Major Cation and

Anion Constituents of Thermal Water

Collected During Pump Test of CD-1. . . . . . . . . 44 


\section{LIST OF TABLES}

Page

Table 1: Chemical Analyses of Callente Waters

(Trexler and others, 1980a) . . . . . . . 35

Table 2: Hydrogen and Oxygen Stable Isotope Analysis - Caliente Waters (Trexler and others, 1980b)....................... 37

Table 3: Comparison of Caliente Drinking Waters, CD-1 Geothermal Waters and Public Health Standards for Potable Water (1962). . . . . . . . 41 


\section{IIST OF PLATES}

Plate 1: Line-shaft Pump with $10 \mathrm{ft}$. Sucker Tube . . . . . . . 50

Plate 2: Installing pump in well cD-1............... 50

Plate 3: Flow-testing CD-1 with Varible Speed Motor. . . . . . . 51

Plate 4: Temperature and Discharge Measuring Technique, CD-1 . . . 51

Plate 5: Discharge of CD-1 into Drainage Ditch . . . . . . . 52

Plate 6: Measuring Temperature $\mathrm{CD}-1,80^{\circ} \mathrm{C}, 178^{\circ} \mathrm{F} \ldots . . . . . .52$ 


\section{INTRODUCTION - SCOPE OF PROGRAM}

The City of Caliente's Interest in geothermal energy has grown from a perfunctory acknowledgement of the resources existence in the City's boundaries to a resounding affirmation of the City's need to utilize the resource to its fullest potential. This ongoing metamorphosis of thought and opinion is largely due to the contributions of people and events in harmony with this beneficial natural resource.

In the summer of 1978 , Fergus G. Wallis of Agua Caliente was awarded an "Appropriate Energy Technology" grant for his traller court in Caliente. It was an extremely successful venture and Fergus encouraged the City of Caliente to join him in his efforts by seeking ald to procure the hot water for a city-wide District Heating System. It was through his encouragement that the City was spurred on to look for aid in getting assessment work done on the resource.

An unsolicited application to the U.S. Department of Energy eventually brought about two studies. Preliminary assessment work was done by Dennis Trexler and Thomas Flynn of the Nevada Bureau of Mines and Geology at the University of Nevada, Reno, and the Oregon Institute of Technology's Gene Culver provided the technical study for the district heating system. Through the efforts of Dennis Trexler and Thomas Flynn, two sites were selected as future test sites to meet the requirements of the oIT study which indicated a necessity for 160 degree Fahrenhelt water at $850 \mathrm{gpm}$. OIT's study addressed then known energy costs in the community and found the project definitely feasible. Everyone concerned with the Callente resource felt these two studies would be the building blocks for the City's future energy supply.

The City again made application for another grant and was successful 
In procuring an "Approprlate Energy Technology" grant for approximately $\$ 50,000$. The purpose of this grant was to drill two wells in hopes of finding the necessary water supply and temperature. Polftical support for the project was helpful as Senator Laxalt and Senator Cannon gave unyielding support from the very beginning. I am positive that without their support we would never have gotten the Nevada Bureau of Mines or the ort study, much less the "Appropriate Energy Technology" grant. It is important we acknowledge and thank them for their efforts on our behalf. Delays in the project almost cost the City its grant, but fortunately through the efforts of our well driller, Fred Anderson, and our consulting geologist, Thomas Flynn, the project was turned around. The day the well driller arrived was confusing to say the least. Richard Gundry, the BLM representative, was there to monitor the project as it was anticipated we would be drilling on their property. Fred Anderson, however, looked at what property we would be drilling on and determined we should wait for Tom Flynn's arrival to make the final determination. When Tom Flynn arrived, Fred had placed his equipment at a point close to the proposed drilling site. Tom Flynn found this point to be the most Ideal. It was in more than one way. First of a11, it was conventent from a driling and geologic point of view, but equally important was the fact that it was situated on an acre of private land owned by Jin wilkin Trucking. The project underway, the CIty negotiated and bought the land. It was at this point the city found Itself in hot water - the test well produced a potable 180 degree Fahrenheit stream of water and the City owned the property it was located on.

The grant objectives complete, the city of Callente is pursuing an aggressive profile as far as procuring a production well. The land is being surveyed and filing on appropriating the water is being initiated. We expect 
to be opening bids for drilling and developing a 16 inch production well by May 20,1983 .

The next steps will probably be every bit as arduous as the past steps have been. Decisions are going to be made that will determine the course of the City's resource. The economic impact of displacing electrical energy sold by the City utility will need to be addressed. Making a priority of industrial application to work toward the ultimate aim of producing a viable and cost-effective district heating system will be surveyed. None of us pretend to have these answers, but we do have our goals. They need to be carefully inaugurated and skillfully applled so that an equally devastating trade-off does not occur.

The aim of the City is to provide this alternate energy source for the benefit of the user and the benef it of the community by operating it through the city utility. It is by this means that the general public will always be the ultimate beneficiary. Caliente is a small communty in need of steady, healthy growth and it is hoped the resource will promote the area for Ifght industry and geothermal related activity. A group in the community is already exploring the possibility of utilizing the waters for a health spa to promote the present sagging economy. The City will have to interface with these and other groups to insure a beneficlal effect.

The pursuance of additional federal grants is not ruled out. On the contrary, we will be making an aggressive move in this direction to Insure that every possibility has been researched. We will be making trips to survey what other communities have done and we will also make ourselves avallable to show other communities what we have accomplished. The entire project will require money and we are open to the possibility of acquiring investors so long as the primary benefit to the community is not jeopardized. 
.

The $\$ 50,000$ "Appropriate Energy Technology" grant provided by the U.S. Department of Energy has been money well spent in Caliente as the ensuing report will testify. It is our hope that others will find the report as beneficial to their needs as we have found the work accomplished in this report beneficlal to ours. Our special thanks to Thomas Flynn, our consulting geologist, for a job expertly and professionally done.

\author{
Keith Larson \\ Mayor \\ City of Caliente \\ Apri1, 1983
}




\section{BXECUTIVE SUKMART}

Two geothermal test wells were drilled in January, 1983, in Antelope Canyon to access the potential for resource utilization by the city of Callente's proposed space heating district. Both holes, drilled into bedrock at 220 feet, encountered hot water in the upper part of the hole (40 to $100 \mathrm{feet}$ ) and cooler water below (100 to 210 feet). Temperaturedepth profiles measured in the two holes are nearly identical, and are similar to profiles measured in existing nearby wells. Lithologic logs constructed from drill chip samples reveal that a clay layer, in the vicinity of the temperature reversal, represents an aquiclude that 1 imits fluid mixing. The diameter of well CD-1 was subsequently Increased from 6 inches to 14 inches to a depth of 100 feet. The well was cased with 40 feet of $85 / 8$ inch diameter screen in the production zone. Well completion consisted of gravel packing, swabbing and jetting with Barafos solution to remove entrapped drilling flulds, installation of a gravel-fill tube, and cementing the upper 42 feet of the blank-cased hole.

A series of pumping tests were completed in February, 1983, Including pump-efficlency tests, stepped draw-down tests, and 1-,2-, and 3-day sustained pumping tests. The test results indicated that the transmissivity of the thermal aquifer is very, very high. A pumping rate of 255 gallons per minute at $80^{\circ} \mathrm{C}\left(178^{\circ} \mathrm{F}\right)$ may be considered a minimum. Drawdowns of 3 to 6 feet were recovered instantly after pumping was stopped. Pumping of this well had no apparent effect on the water levels of two nearby observation wells. Significant temperature increases were recorded in both observation wells during the last few days of the tests.

Five water samples were collected for chemical analyses during the course of $\mathrm{CD}-1$ pump tests. The samples were collected to determine the 
water quality for the proposed space heating district and possible reinjection, and to establish a water chemistry base-line for comparative analysis of fluid chemistry during the course of the pumping and from subsequent development. In addition, the chemical data were compared to existing analyses of thermal and non-thermal waters in Caliente. The results of these analyses Indicate little or no change in composition over the period of pump testing, and demonstrate a high degree of correlation with nearby thermal fluids. The water quality meets state health standards for all chemical constituents and may be used as a source of potable water. Chemical geothermometers indicated that the maximum temperatures from this resource range from 120 to $140^{\circ} \mathrm{C}$. The highest temperature measured in this resource is $96^{\circ} \mathrm{C}$. 


\section{ACKNOWLEDGEMENTS}

The work that is summarized in this report reflects the action, participation and cooperation of virtually the entire City of Caliente. Mayor Keith Larson is recognized as the principal instigator, but I'm sure he would agree that without the support and capabilities of many other Individuals, this program would still be at square one. I would personally like to thank the Mayor and the people of Caliente for their support, their contributions and, most importantly, their positive attitude and interest in the outcome of this project. I'll probably leave someone out, but I would like to acknowledge Glen Van Roekel and Carol Rosenwood; the members of the City Council, Mike, Paul, Jonathan and Tom; the Rotary Club; Joe and Sally Wing and their children; Jin Wilkens; Fergus Wallis; everybody at the Hot Springs Motel and Branding Iron; and special thanks to Henry, Mike and Bob at the Swaller and Holler Cafe. In addition, we should all thank Fred and Shelley Anderson for drilling the holes and Darryl and Albert Free, and Dwayne for pumping the well. In Reno, I'd like to thank the people who helped prepare the reports including Cam Covington, 11lustrator; Susan Parkhurst, typist and organizer; and my wife Pat for typing and patience with my grammar and spelling. Lorraine Bruce provided needed assistance during completion of $C D-1$, and interpreted the hydrologic data from the pump tests. Finally, I'd like to thank the staff and management of PLANN ENGINEERING for their layout work and for keeping it all under budget. 
DRILLING REPORT 


\section{INTRODUCTION}

In March, 1980, the Nevada Bureau of Mines and Geology (NBMG) completed a preliminary assessment of the geothermal resources of Callente (Trexler and others, 1980). This program was funded by the U. S. Department of Energy (contract no. DE-AC08-79NV10039) and Included collection of existing data, geologic reconnalssance, temperature measurements in springs and wells, two meter-depth temperature probe surveys, and chemical analyses of water and soil samples. The report recommended that two test wells be drilled to a depth of 500 feet to confirm the extent of the resource; the drill sites were selected on the basis of geophysical and geologic observations and are shown in Figure 1 (Test Wells \#1 and \#2).

In addition to the Resource Assessment Program, the Nevada Department of Energy requested technical assistance from the Geo-Heat Utilization Center, Oregon Institute of Technology (OIT). The final report, District Heating System, City of Caliente, Nevada, Included an engineer ing and economic study of the feasibility of installing a geothermal district heating system. The report concluded that the proposed district heating system was economically feasible. It assumed a geothermal source capable of dellvering $71^{\circ} \mathrm{C}\left(160^{\circ} \mathrm{F}\right)$ fluids at a peak load of $850 \mathrm{GPM}$, from a relatively shallow depth near the city boundaries. 


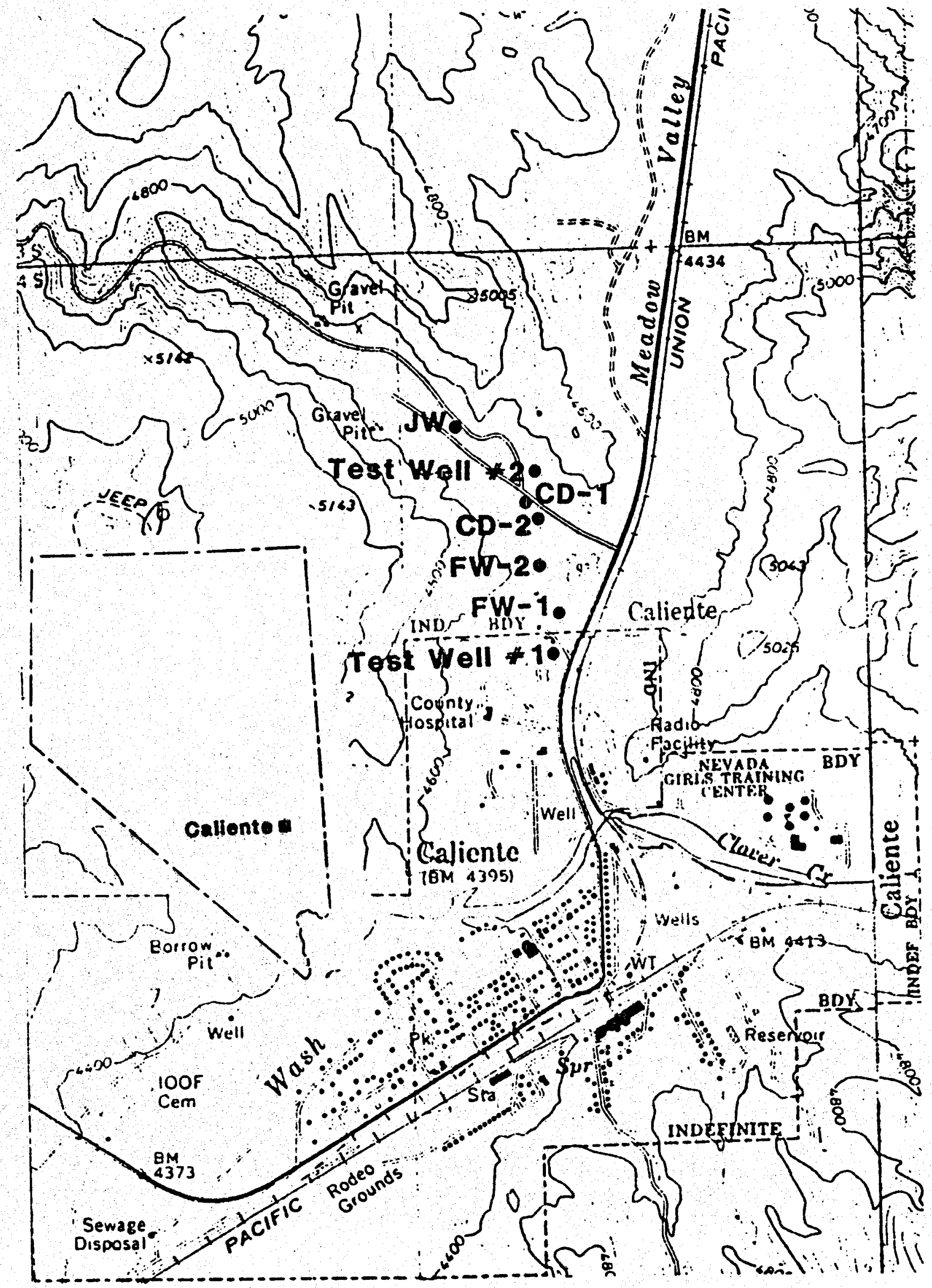

Figure 1: Original Test Well Drill Site Recomendations

(after Trexler and others, 1980a). 


\section{DRILL SITE SELECTION}

The selection of the drill sites was based uitimately on the avallabllity of a 1.3 acre parcel of private land in Antelope Canyon. This parcel of land 18 located adjacent to the drill site (Number 2) recommended by Trexler and others (1980a). The site provided convenlent access and, because it is located in the center of the canyon, afforded a higher probability to penetrate a larger volume of thermal water.

The land parcel is also located between several known thermal wells. FW-1, measured in October, 1978, reached a maximum temperature of $67^{\circ} \mathrm{C}$ $\left(153^{\circ} \mathrm{F}\right.$ ) in the 30 to 70 foot interval (FIgure 2). A slight temperature reversal at the bottom of the well was originally thought to Indicate the bedrock-alluvium interface. Thermal fluids are found throughout Nevada in alluvium, just above the bedrock. It was later determined that these geothermal waters are underlain by cooler waters. This kind of proflle occurs throughout the reservoir and characterizes the nature of the resource. Just west of the land parcel, another thermal well (Figure 3) reached a maximum temperature of $80^{\circ} \mathrm{C}\left(176^{\circ} \mathrm{F}\right)$ at a depth of approximately 80 feet. A olight temperature reversal can also be seen at the bottom of this well. Based on the availability of private land, and the facts discussed above, a decision was made to drill at least one test well on this parcel. 

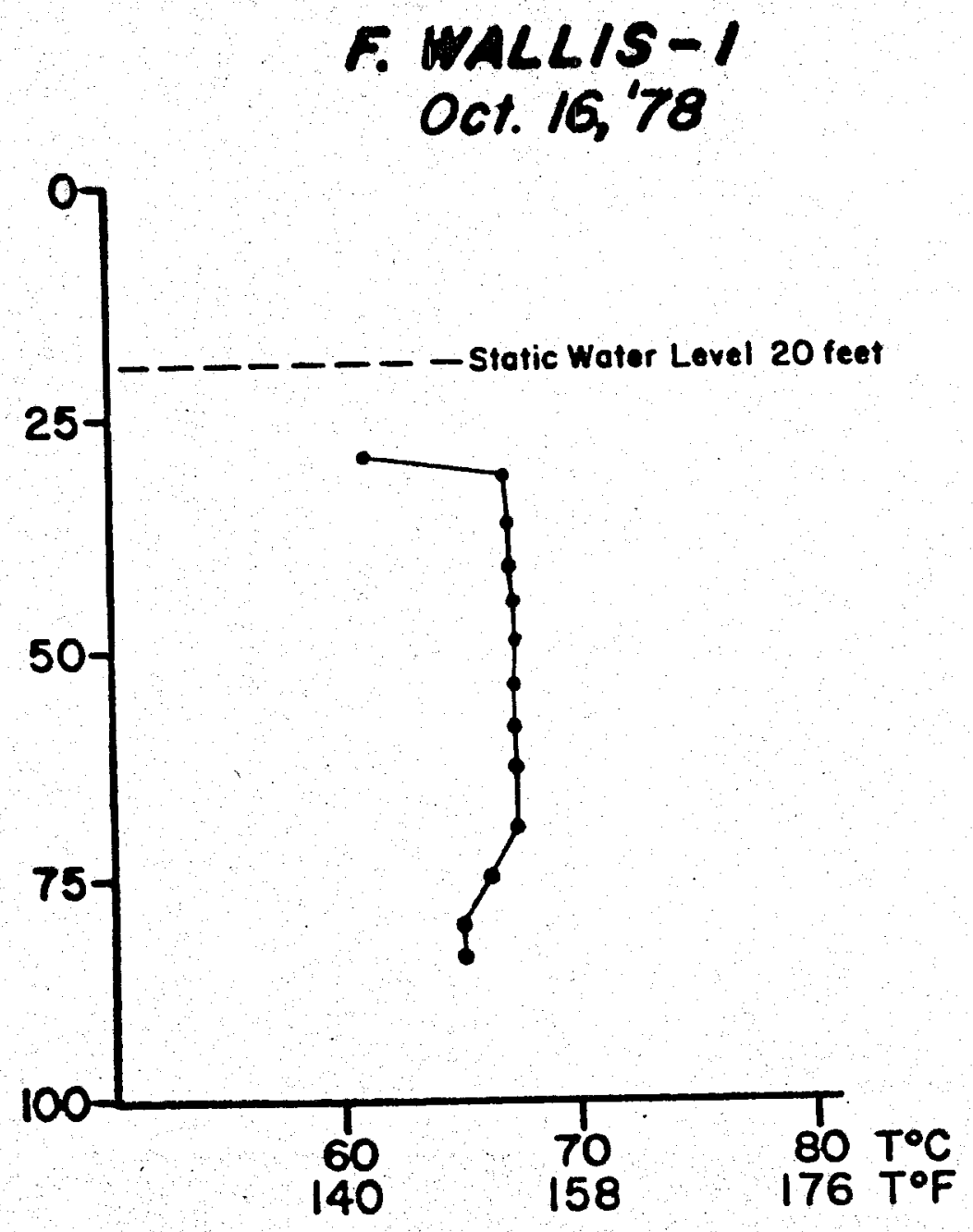

Figure 2: F-Wallis-1 Geothermal Well
Temperature-Depth Profile 


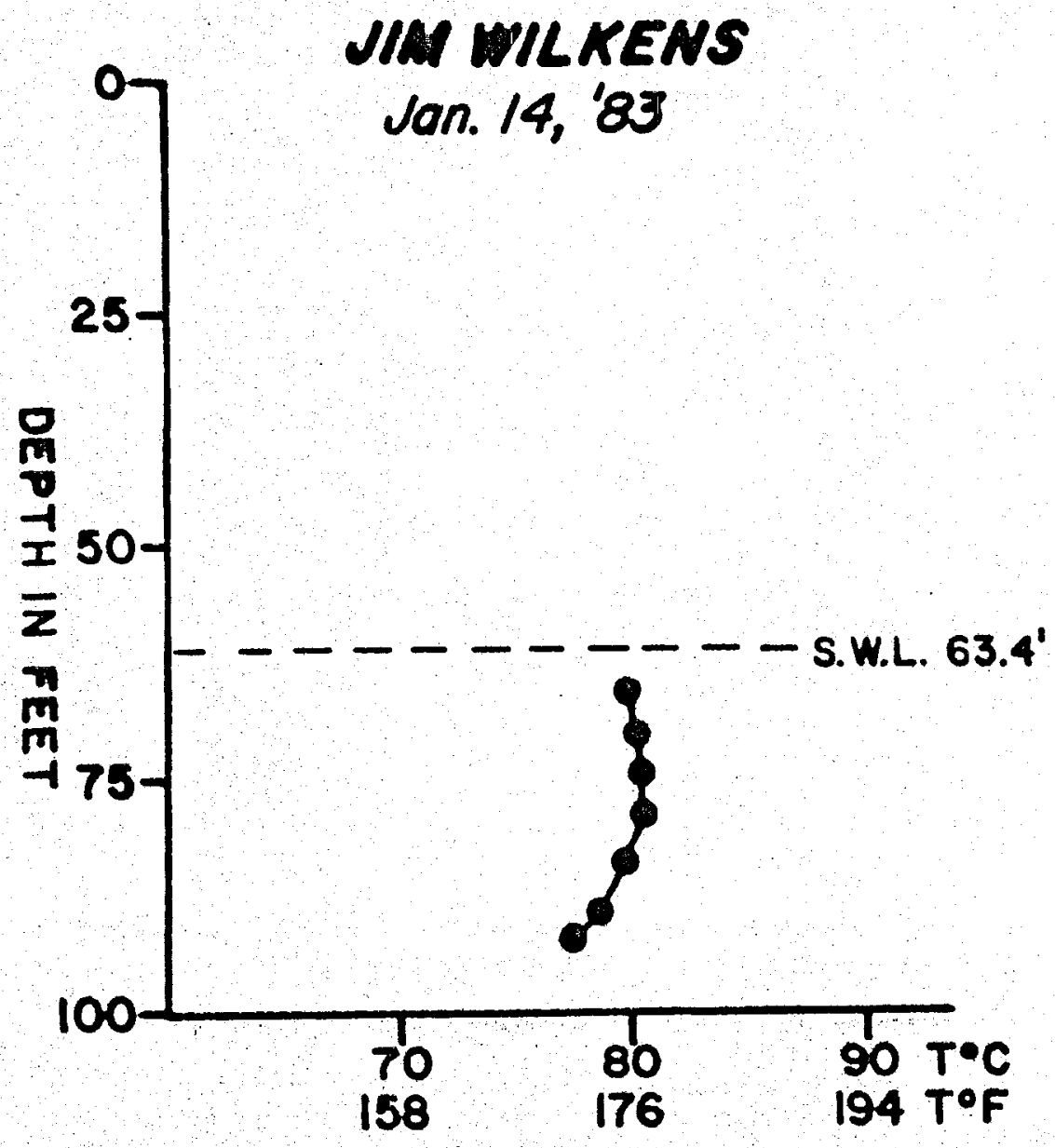

Figure 3: J-Wilkens Geothermal Well Temperature-Depth Profile

) 


\section{DRILLING SPECIFICATIOH AND MONITORING TECBNIQUES}

All drilling was performed by Fred Anderson and Son Exploration Drilling Co., Woods Cross, Utah. The dr111 rig used was a Portadr111 524 rotary air/ mud rig with a $38 \mathrm{ft}$. mast and a $20 \mathrm{ft}$. kelly. A $6 \frac{1}{2}$ Inch dlameter tri-cone button bit and $20 \mathrm{ft}$. by 3 inch dlameter dr111 rods were used throughout the drilling operation. A portable mud-tank (350 gal.) was used for each hole and high yield bentonite drilling mud was used throughout the operation. An attempt was made to maintain mud viscosity at 55 .

Temperatures of return mud flow were measured and recorded at 10 foot intervals using electronic digital thermometers. Temperatures were monitored continuously during the drilling operation. Drill chlp samples were collected at 10 foot intervals. A brief description of the chip samples was included with the measured temperature and entered into the daily drilling report, which was submitted dally to the City of Caliente. 


\section{SURALAY OF DRILLING ACTIVITIES, HOLES CD-1, CD-2}

Date Activity Sommary

Jan. 14 Set up rig on Wilkens' property. Drilled to total depth of $100 \mathrm{ft}$. Naximum return mud temperature was $35^{\circ} \mathrm{C}\left(95^{\circ} \mathrm{F}\right)$. First encountered water at about $40 \mathrm{ft}$.

Jan. 15 Measured temperature profile in mud to $65 \mathrm{ft}$. (Figure 4). Maximum temperature was $73.5^{\circ} \mathrm{C}\left(164^{\circ} \mathrm{F}\right)$. Tripped into hole at $90 \mathrm{ft}$, lost $10 \mathrm{ft}$. to sloughing. Drilled to $220 \mathrm{ft}$. T.D. Samples 210 and 220 are homogeneous rhyolite (probably bedrock). Drill rate also decreased. Maximum return mud temperature was $41^{\circ} \mathrm{C}\left(106^{\circ} \mathrm{F}\right)$.

Jan. 16 Measured temperature profile in mud to $188 \mathrm{ft}$. (Figure 4). Temperature reversal occurs at about $100 \mathrm{ft}$. Cooler waters underlie hot waters. Recomend flushing and out of hole with clear water. Begin to ream out top of hole to place conductor - lose top of hole. Spend remaining time reaming out hole to T.D. of $120 \mathrm{ft}$.

Jan. 17 Cased CD-1 with 2 In. diameter steel pipe to $100 \mathrm{ft}$. Flush hole with clear water. Return in the afternoon to complete temperature-depth profile (Figure 5). Maximum temperature measured was $64.5^{\circ} \mathrm{C}\left(148^{\circ} \mathrm{F}\right)$ at $100 \mathrm{ft}$. 


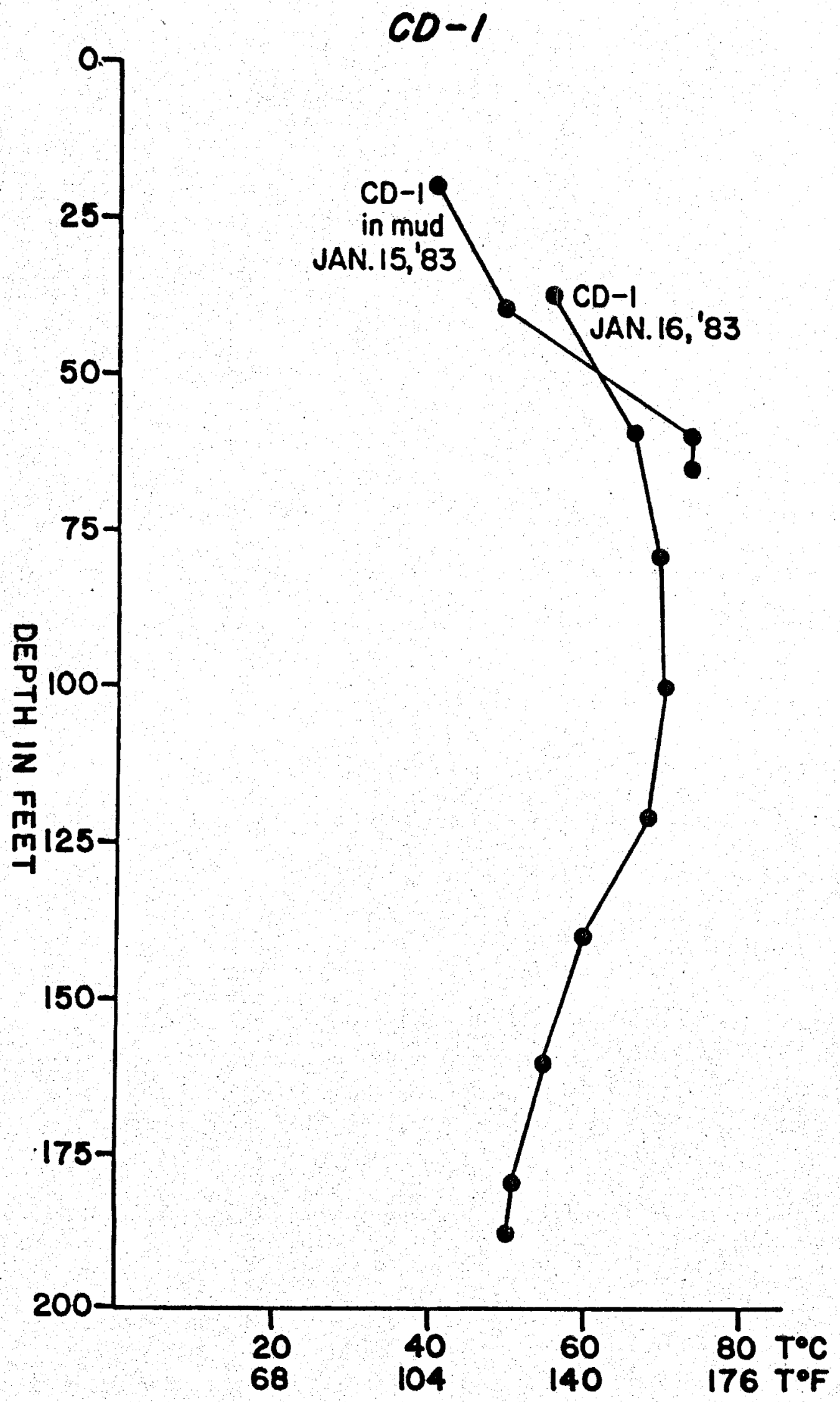

Figure 4: Temperature-Depth Profiles of CD-1, Jan. 15-Jan. 16, 1983 

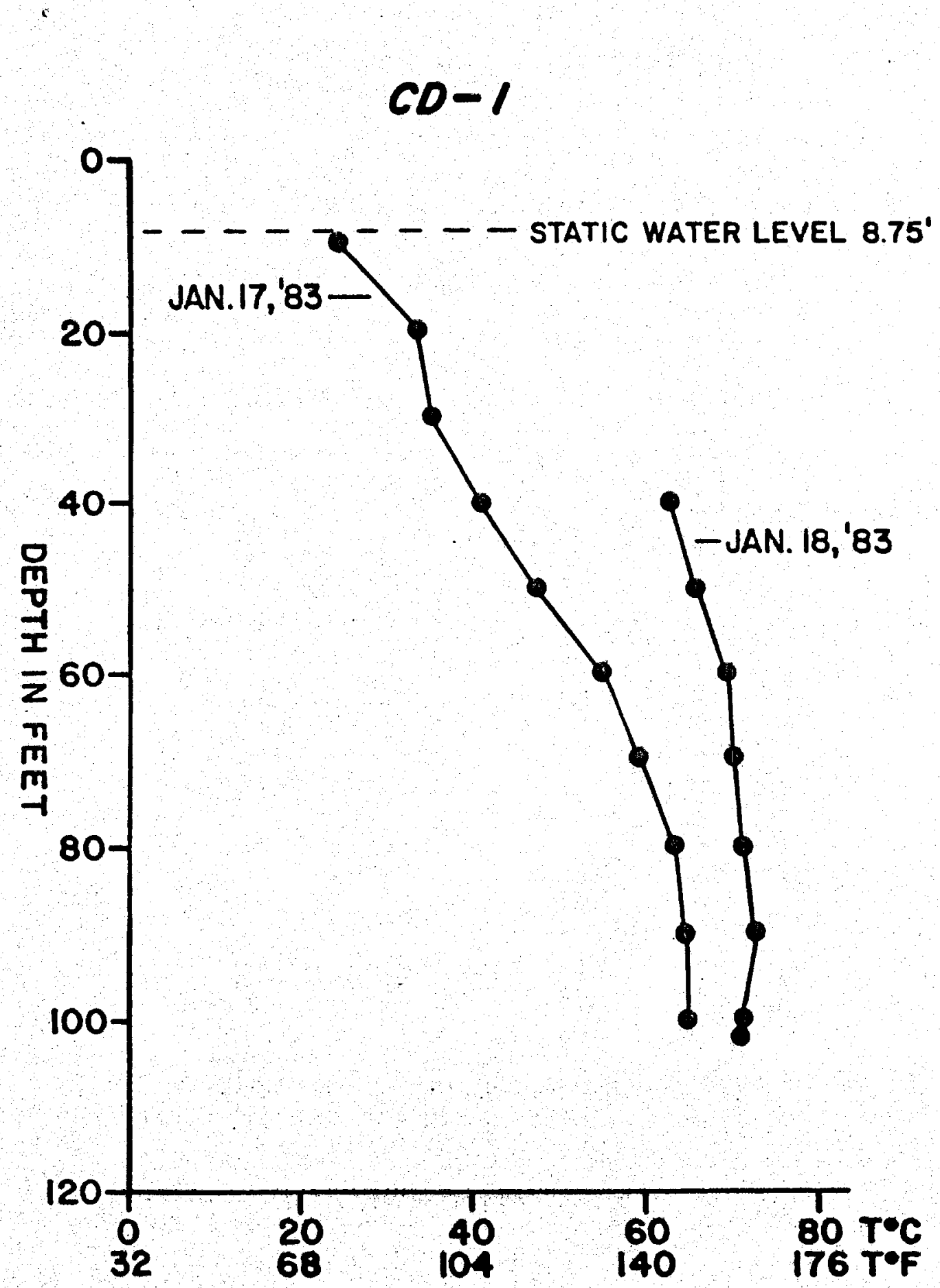

Figure 5: Temperature-Depth Profiles of CD-1, Jan. 17-Jan. 18, 1983 
Date Activity Summary

Jan. 18 Complete another temperature profile on CD-1 from 40 to $90 \mathrm{ft}$. Well appears to be 1sothermal from 70 to $85 \mathrm{ft}$. with slight temperature reversal near bottom of hole (Figure 5). Temperature reversal is coincident with layer of clay found In drill chips. (Met with Mayor to suggest we copplete CD-1 as a 12 inch dlameter production hole - case bottom $40 \mathrm{ft}$. with fine screen and gravel pack to $50 \mathrm{ft}$ - cement seal top $50 \mathrm{ft}$. around blank casing - prepare for pumping test. Further suggest drilling an observation well to bedrock 100 to $200 \mathrm{ft}$. from (D-1.) Moved rig off CD-1 $150 \mathrm{ft}$. to the east. Rig-up for drilling - complete hole to $20 \mathrm{ft}$.

Jan. 19 Drilled $\mathrm{CD}-2$ to total depth of $200 \mathrm{ft}$. with a maximum return mud temperature of $42^{\circ} \mathrm{C}\left(108^{\circ} \mathrm{F}\right)$. Drill chips similar to CD-1, somewhat more clay.

Jan. 20 Complete drilling CD-2 to $220 \mathrm{ft}$. Bottom-out in rhyolite. Return mud temperature approximately $30^{\circ} \mathrm{C}\left(86^{\circ} \mathrm{F}\right)$. Case hole to $220 \mathrm{ft}$. with 2 Inch diameter steel plpe. slots cut in bottom $160 \mathrm{ft}$. to provide formation communication. Flush with clear water.

Jan. 21 Complete temperature-depth profile of $\mathrm{CD}-2$ to $220 \mathrm{ft}$. (Figure 6). Temperature reversal occurs at approximately $95 \mathrm{ft}$. 


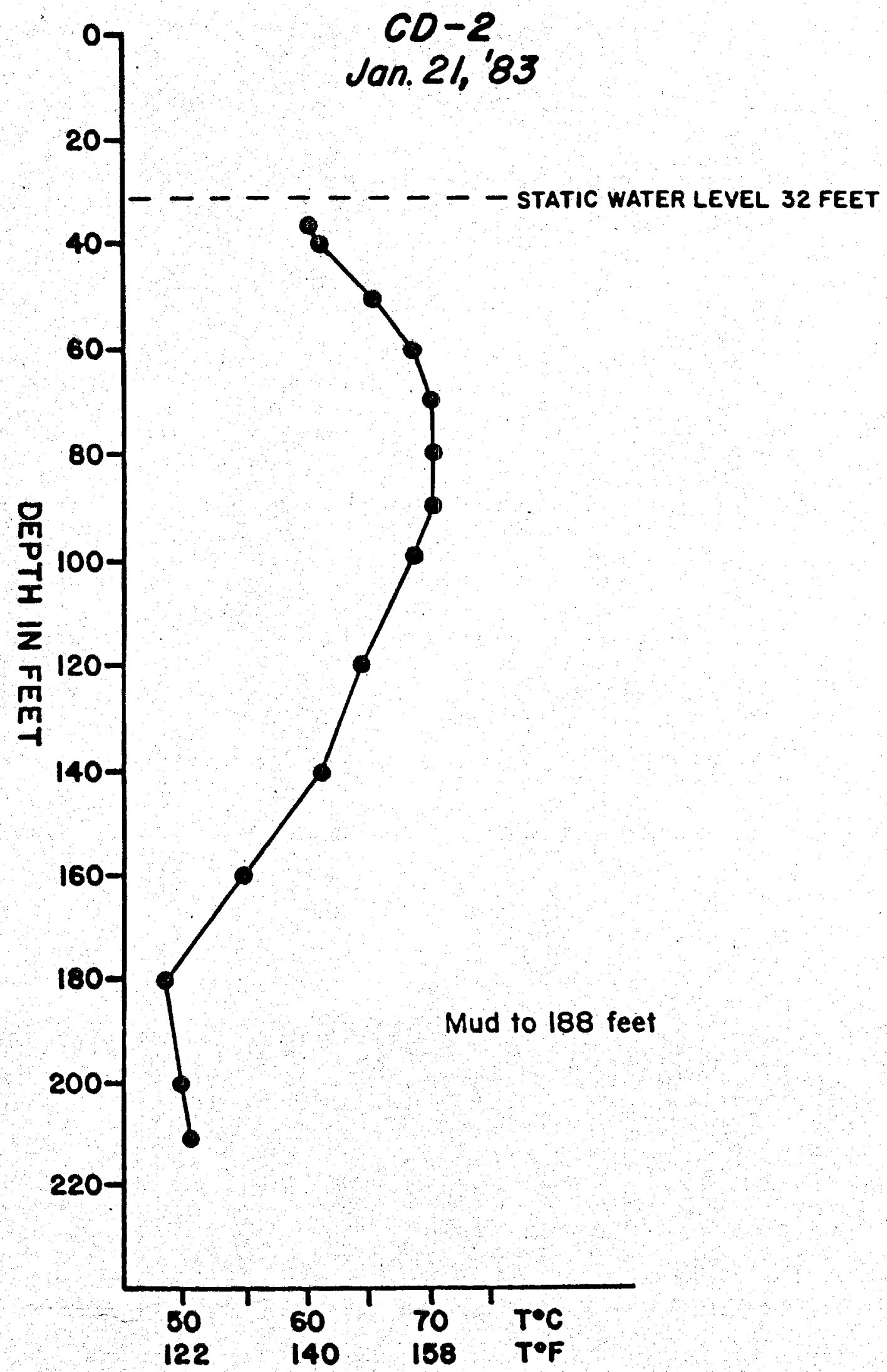

Figure 6: Temperature-Depth Profile of CD-2, Jan. 21, 1983 


\section{ANALYSIS IOF DEILL HOLE DATA, CD-1, CD-2}

Combined analysis of temperature-depth proflles (FIgures 4,5 , and 6) and Ithologic logs (FIgure 7) from drill holes $C D-1$ and $C D-2$, in conjunctIon with temperature gradients measured in nearby wells (FIgures 2 and 3) show that geothermal fluids in Antelope Canyon are widespread, but are restricted to a zone located between 40 and 100 feet below the surface. Thermal waters in Antelope Canyon are underlain by cooler waters, which are in turn underlain by rhyolite bedrock. A maximum temperature of $81^{\circ} \mathrm{C}$ $\left(177^{\circ} \mathrm{F}\right)$ was measured in J. Wilkens' well.

The aquifer for both thermal and non-thermal waters is young alluvium and consists of varying proportions of sand and gravel with clay-rich fractions and occasional layers of larger cobbles and boulders. The material is all locally derived and consists largely of Prospect Mountain quartzite and Cretaceous-Tertlary-age rhyolites. Minor basalt, shale, and carbonate are also present.

Temperature reversals in both drill holes clearly delineate the lower boundary of the thermal waters. Clays found in dr111 cuttings from both holes are coincident with the temperature reversal and 11 kely form a semipermeable barrier (quasi-aquiclude) between the two waters. The probable source of the cold waters is Meadow Valley Wash, but the Antelope Canyon drainage also represents a possible contributor. Mixing of thermal and non-thermal waters is probably occuring naturally throughout Antelope Canyon. The source of the thermal waters is not known for certain. A Iikely candidate is the hydrothermally altered carbonate, which has been thrust over the Prospect Mountain quartzite. The carbonate dips at approximately $90^{\circ}$ and strikes $\mathrm{N} 30^{\circ} \mathrm{E}$ across the canyon, approximately 500 feet west of $C D-1$. The source of the heat is probably the result of deep 


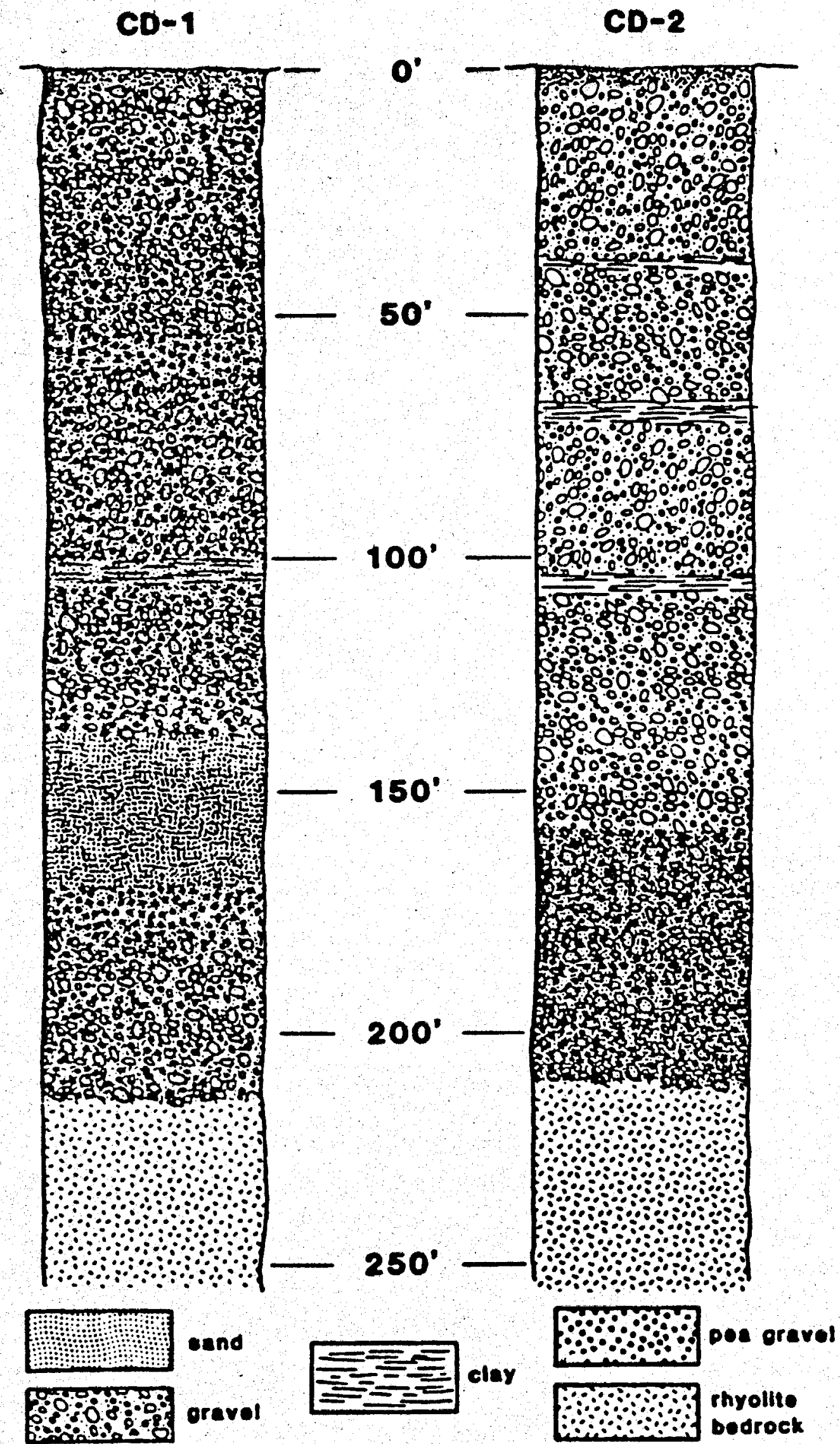

Figure 7: Lithologic Logs of Drill Holes $C D-1$ and $C D-2$ 
circulation along faults. Pllocene-age basalts mapped west of Callente In Dry Lake Valley (Tschanz and Pampeyan, 1970) should not be ruled out. 
WELI COMPLETION ARD

PUKP TESTS 


\section{INTRODUCTIOR}

This section describes the aquifer tests for Production Hole $C D-1$; water levels and temperature gradient measurements for Observation Wells $C D-2$ and $J W$ are also included.

Test hole CD-1 was completed as a production well to a depth of 100 feet. Temperature-depth measurements showed a dramatic temperature reversal below 110 feet, and the well was completed in the zone that contained the high-temperature fluids. A completion diagram of Hole CD-1 is shown in Figure 8.

Hole CD-2 was drilled nearby as an observation well to a total depth of 220 feet. CD-2 was cased with 2-Inch diameter steel tubing that had torch-cut slots in the bottom 160 feet of casing. Water levels and temperature gradients were measured dally in $\mathrm{CD}-2$ and in another well (JW, 600 feet northwest of $(D-1)$ prior to, during, and after pumping CD-1. 


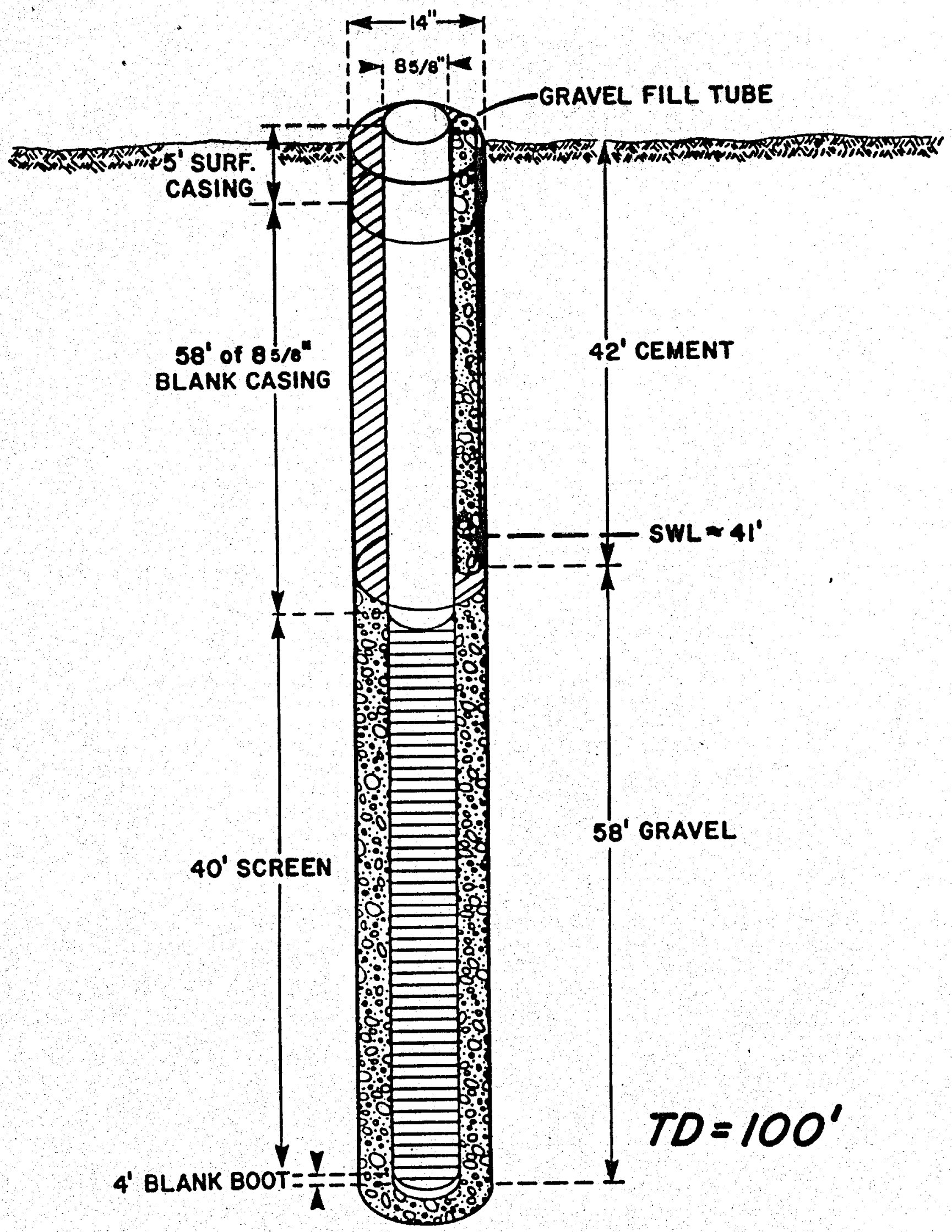

Figure 8: Well Completion of CD-1 


\section{PUKPIHG AND KRASURIKG SPECIPICATIONS}

All pump tests were completed using down-hole line shaft bowl-type pumps. Power was provided by a varlable-speed gasoline-powered automobile engine for the step-drawdown test. A constant-speed $30 \mathrm{HP}$ electric motor (1760 rpm at $440 \mathrm{~V}$ ) provided power during the sustalned pump tests.

The inftial pump used was an elght-bowl $7 \frac{1}{2}$ inch diameter Berkeley pump. This pump developed mechnical problems and was replaced with a smaller ( $6 \frac{1}{2}$ Inch dlameter 6-bowl Berkeley), more efficient pump.

The pumps were set in the well to 67 feet below the ground level. A 10 foot length of $4 \mathrm{lnch}$ dlameter tubing (sucker tube) extended below the pump. The actual pumping depth was 77 feet below ground level.

Discharge measurements were made by timing the filling of a 5 gallon pail at a known rpm. Extrapolation of these data were used inftially to estimate discharge at high rpm. Another method was used to confirm measured flow rates. Water flow from a full 4 Inch dlameter pipe may be calculated by measuring the horizontal distance from the edge of the discharge pipe to the top of the stream of water when the top of the water 1 s one foot below the top of the pipe. The horizontal distance is multiplied by a factor of 13.1 to obtain discharge in $\mathrm{gpm}$. This method was used in 11 eu of a flowmeter.

Temperatures of discharging flulds were measured with mercury-in-glass thermometers that were accurate to $0.2^{\circ} \mathrm{C}$. Down-hole temperatures in observation wells $\mathrm{CD}-2$ and $\mathrm{JW}$ were measured with an Envirolabs cable-reel digital thermometer with an accuracy of $0.1^{\circ} \mathrm{C}$.

Water levels were measured in Hole $C D-1$ using a gas charged 63 foot air IIne with a direct reading depth gauge, accurate to 0.5 feet. The air 
Ine gauge was callbrated agalnst an electric sounding probe with an estimated accuracy of 0.1 foot. Water levels in observation wells were measured with the electric sounding probe.

Five water samples were collected during the course of the pump tests. These samples were subnitted to a comerclal laboratory for analysis of approximately 20 dissolved species. Results of these analyses are described in the following section. 


\section{SUMARY ÖF DAILY ACTIVITIES}

Date

Feb. 15, 1983 Arrive at CD-1, begin development of well by pumping and surging; calibrate pump rpm and discharge. Water temperature stable at $80^{\circ} \mathrm{C}$. Water clear at low discharge, sandy at high discharge. Determine pump is not efficient and should be replaced. Measure water levels and temperature gradients in observation wells $C D-2$, JW. Remove pump from well.

Feb. 16, 1983 Install new pump in well. Callbrate pump discharge vs. rpm. Surge well; conduct three, 2 hour step-drawdown tests, $200,250,300 \mathrm{gpm}$.

Feb. 17, 1983 Install $30 \mathrm{HP}$ electric motor on pump (1760 rpm at 440 volts). Measure water levels and temperature gradients in observation wells $C D-2, J W . ~ B e g$ in sustained pump test at $11 \mathrm{am}$. Measure drawdown, discharge, water temperature.

Feb. 18, 1983 Continue pump test until 13:17; strong winds (50-60 mph) result in power fallure. Measure recovery. Measure water levels and temperature gradlents in observation wells CD-2, JW.

Feb. 19, 1983 Begin sustained pump test $\$ 2$ at 8 am. Measure water levels and temperature gradients in observation wells $C D-2$, JW. 
Feb. 20, 1983 Cont Inue pump test 12 . Continue to monftor observation wells CD-2, JW.

Feb. 21, 1983 Cont inue pump test \#2. Continue to monitor observation wells $C D-2$, JW.

Feb. 22, 1983 Stop pump test \$2 at 8 am. Measure recovery. Mechanical failure, repair pump. Begin pump test $\# 3$ at $14: 00$ hours. Continue to monitor observation wells $\mathrm{CD}-2$, JW.

Feb. 23, 1983 Continue pump test \#3. Continue to monitor observation wells $C D-2, \mathrm{JW}$.

Feb. 24, 1983 Stop pump test $\$ 3$ at 14:00 hours. Measure recovery. Pul1 pump. Monitor observation wells CD-2, JW.

Feb. 25, 1983 Measure temperature gradients and water levels in CD-1, $\mathrm{CD}-2$, JW. Temperature Increase in $\mathrm{CD}-2$ and JW. Leave for Reno. 


\section{CD-1 AQUIFBR TEST}

\section{Flnd Ings}

1. The pump test results indicate that $C D-1$ will produce water at a minimum rate of 255 gallons per minute at a constant temperature of $80^{\circ} \mathrm{C}$.

2. The aquifer is highly transmisslve and will yleld water at a higher rate of production.

3. Pumping $C D-1$ did not affect the water levels in the two observation wells $C D-2$ or JW.

\section{Recommendations}

1. During production of $\mathrm{CD}-1$, monitoring well performance on a weekly basis should include measurement of water level, temperature and flow rate. A flow meter should be Installed in the system for this purpose.

2. Water levels in $C D-2$ should be monitored if drawdown in $C D-1$ is greater than 30 feet.

3. Water samples should be collected from CD-1 every two months to detect any chemical change occurring with time.

\section{Aquifer Test}

\section{CD-1 Step Drawdown Evaluation}

The purpose of the $C D-1$ step drawdown test was to determine the optimum pumping rate for the constant rate aquifer test and to calculate the Initial specific capacity of the well.

Each "step" consisted of producing the well at the specifled rate for 120 minutes and monitoring the resulting water level decrease. A change in rate for the next production level was accompanied by shutting of the pump, allowing the water level to surge in the well, and starting the pump 
the new, increased rate.

Results from each step are summarized as follows:

\begin{tabular}{|cccc|}
\hline STEP & $\begin{array}{c}\text { PUMPING RATE } \\
\text { (GPM) }\end{array}$ & $\begin{array}{c}\text { DRAWDOWN } \\
\text { (FT.) }\end{array}$ & $\begin{array}{c}\text { SPECIFIC CAPACITY } \\
\text { (GPM/FT.) }\end{array}$ \\
\hline \#1 & 200 & 5 & 40 \\
t12 & 250 & 6 & 41.7 \\
113 & 300 & 7 & 42.9 \\
& & & \\
\hline
\end{tabular}

At each step, the water level decreased within the first two minutes of production and "stabilized" at that level (see Figure 9). The increasing specific capacity results from continuing well development.

The constant production rate selected for the aquifer test was determined by the physical limitations of the pump.

\section{CD-1 Constant Rate Evaluation}

Three separate constant rate pump tests were conducted during a 7day period from February 17 to 24. The production rate in each case was $255 \mathrm{gpm}$, the water temperature was a constant $80^{\circ} \mathrm{C}\left(178^{\circ} \mathrm{F}\right)$, and the static water level was 43 feet. A sumary of each test is as follows:

\begin{tabular}{|cccccc|}
\hline DATE & TEST \# & $\begin{array}{c}\text { LENGTH OF } \\
\text { TEST }\end{array}$ & $\begin{array}{c}\text { MAXIMUM } \\
\text { DRAWDOWN } \\
\text { (FT.) }\end{array}$ & $\begin{array}{c}\text { RECOVERY } \\
\text { TIME } \\
\text { (MIN,) }\end{array}$ & $\begin{array}{c}\text { SPECIFIC } \\
\text { CAPACITY } \\
\text { (GPM/FT.) }\end{array}$ \\
\hline $2 / 17$ & 1 & $26 \mathrm{hrs}$ & 6 & 20 & 41.7 \\
$2 / 19$ & 2 & $72 \mathrm{hrs}$ & 5.5 & 1 & 46.4 \\
$2 / 22$ & 3 & $48 \mathrm{hrs}$ & 5.0 & 1 & 51.0 \\
\hline
\end{tabular}




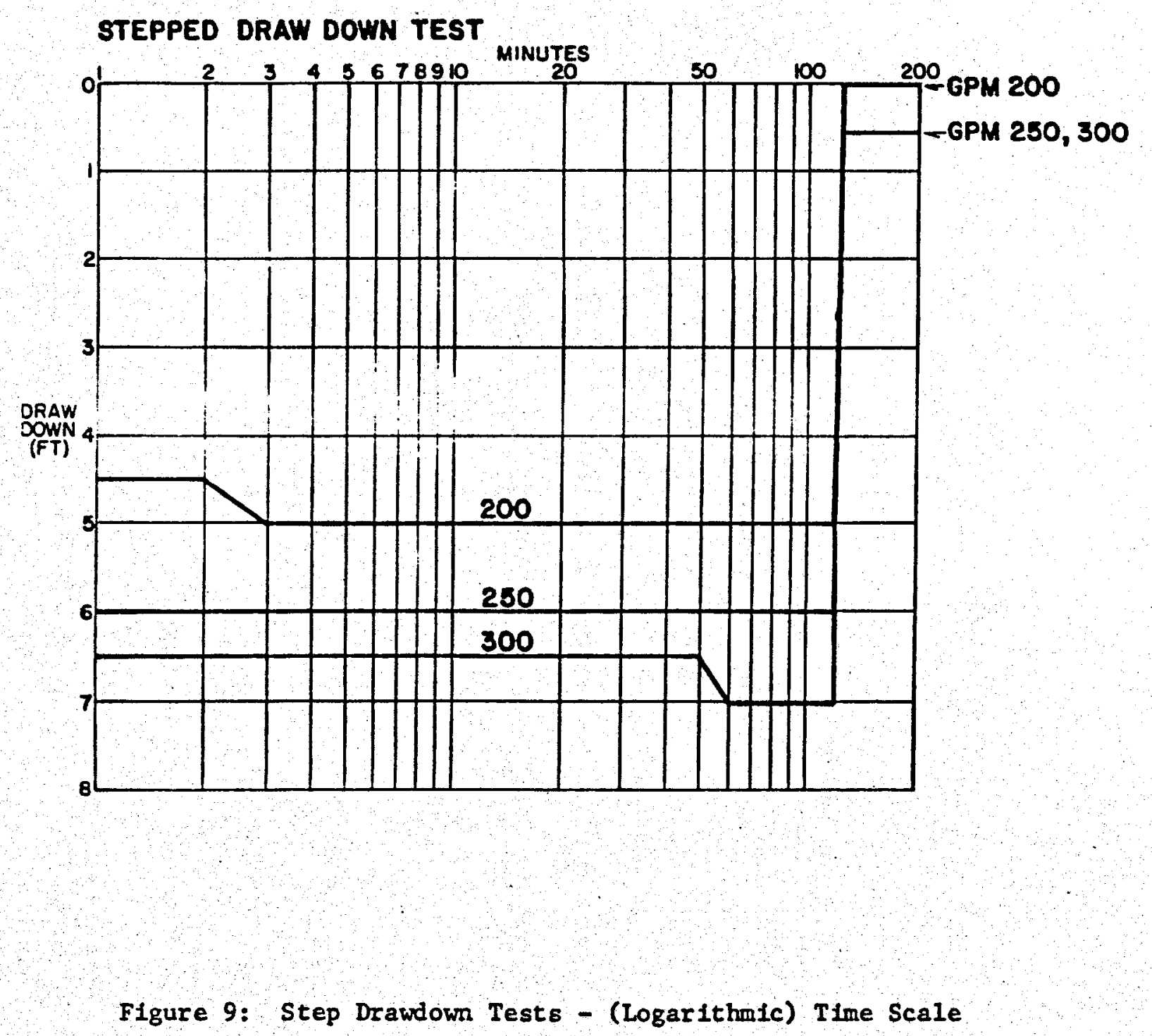


Specific capacity of the well in gallons per minute per foot of drawdown continued to Increase during the three tests and results from continuing well development. Thls phenomenon was also observed during the step drawdown test.

Maximum drawdown during tests $\# 1$ and $\# 2$ occurred within four minutes after pump start-up. Full recovery of the water level to static condition occurred within two minutes after pump shut-down for every test (see Figures 10, 11A, 11B). Such quick responses result from a highly transmissive aquifer.

Because of this high transmissivity, the aquifer test data cannot be analyzed to determine an exact value. Analysis of this aquifer characteristic depends on removing fluid during the pump test at a greater rate than the aquifer will deliver to the well. In this case, water could move through the aquifer at a rate at least equal to the pumping rate of $C D-1$. In order to obtain an exact value of transmissivity, CD-1 must be pumped at a higher rate and for a sufficient period of time to observe a gradual decline in the water level.

Results from this test ind Icate that CD-1 will successfully produce at least 255 gallons per minute at a constant temperature of $80^{\circ} \mathrm{C}$. Considering the general hydrologic response and the gravel-type material, this aquifer could be produced at a higher rate. The exact rate cannot be quantifled with this data.

\section{Observat1on Well Results}

Observation Wells CD-2 and JW, located approximately 150 feet southeast and 600 feet northwest of CD-1 respectively, were monitored during the 7-day pump test period. The initial static water levels were 


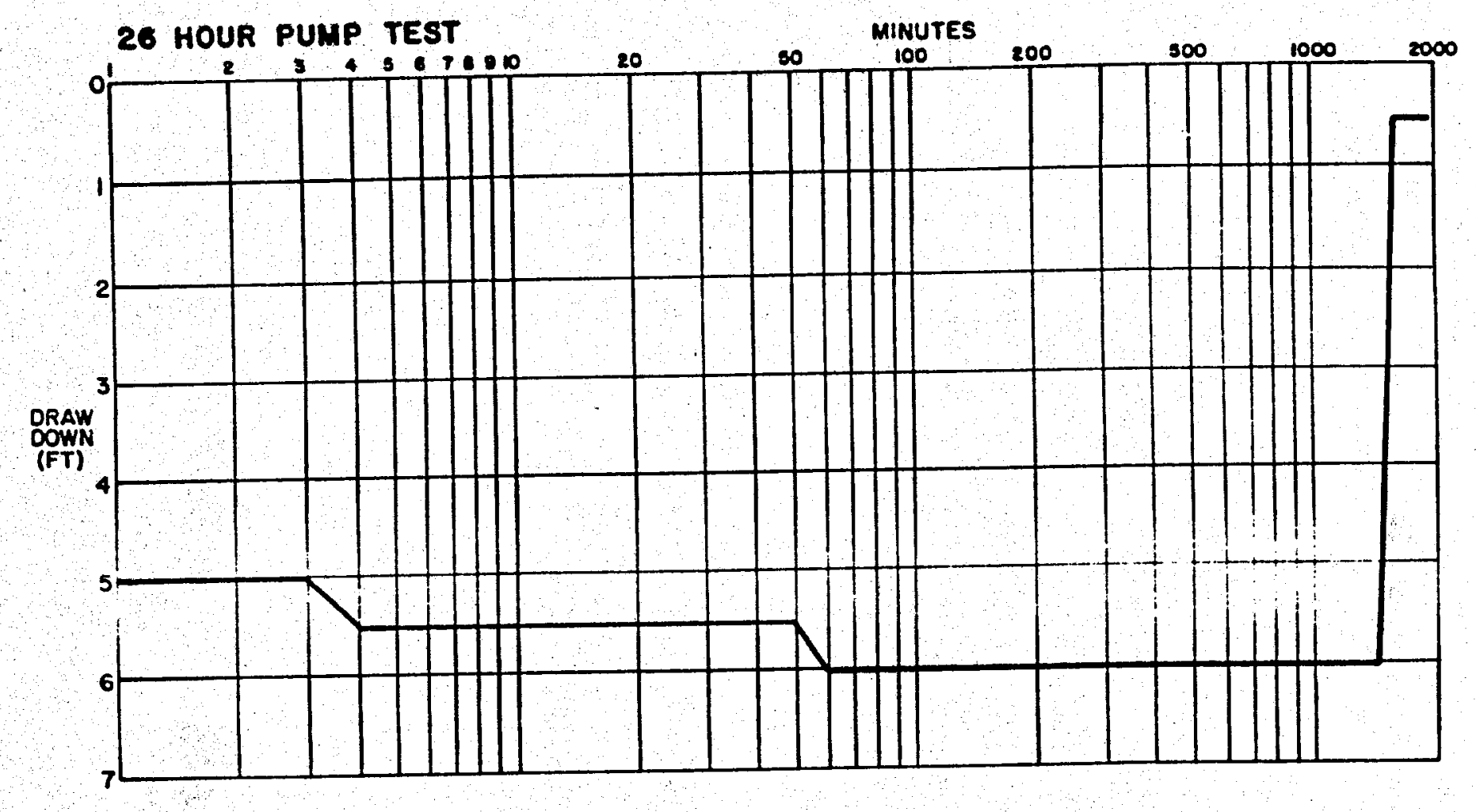

Figure 10: CD-1, 26 Hour Pump Test 


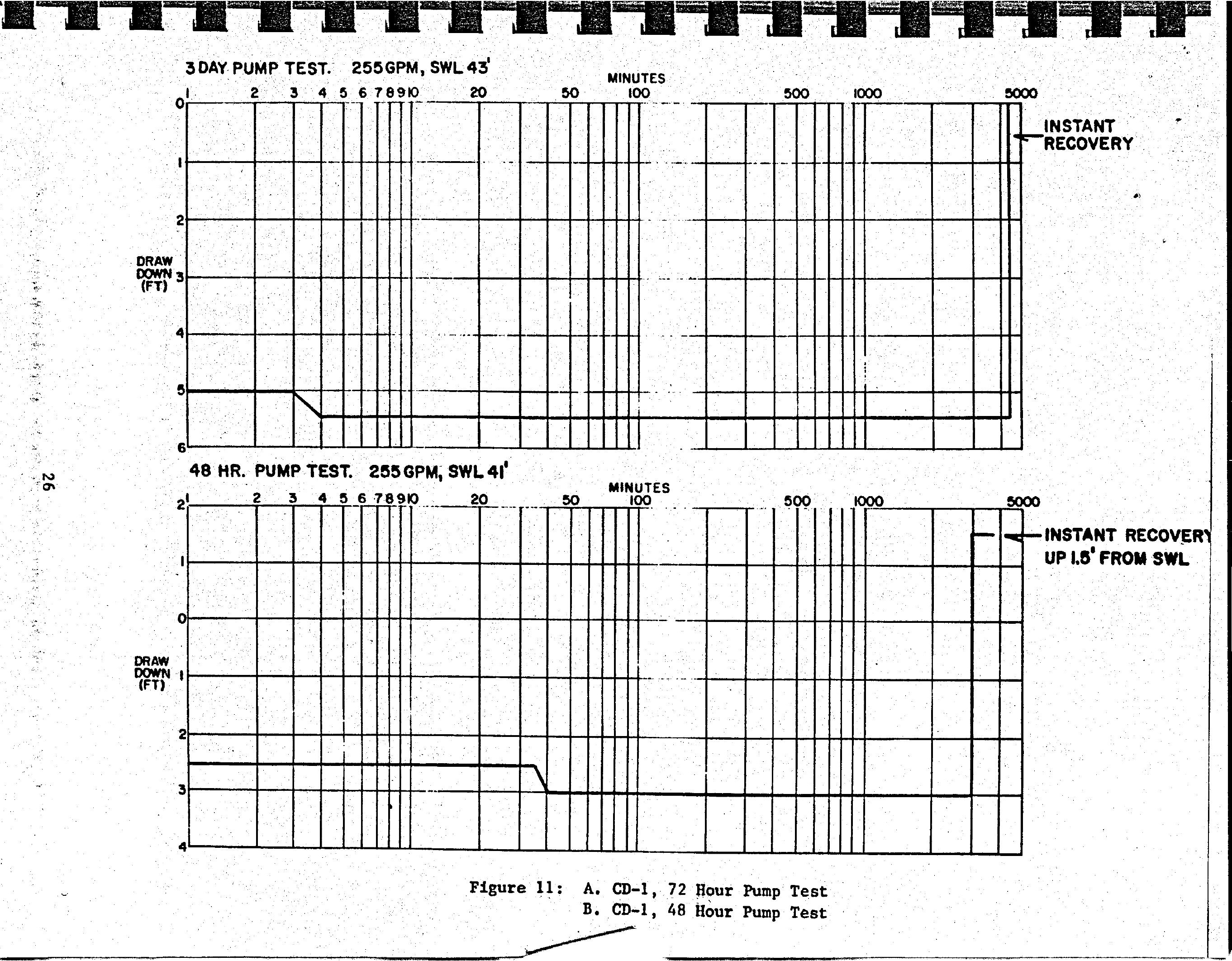


measured on February 15, before any testing of $\mathrm{CD}-1$. Th1s measurement established the depth to water below the top of the casing. The actual water level elevations were not determined because well elevations were not surveyed.

Water levels recorded in both wells during the CD-1 constant rate test showed both increasing and decreasing fluctuations as compared to the static level (FIgure 12). These fluctuations did not result from the CD-1 pump testing. In particular, $C D-2$ showed a maximum Increase of 0.25 feet during constant rate test \#. If the observation well had been affected by the test, a drop in water level would have resulted. Water level fluctuations in both $\mathrm{CD}-2$ and $\mathrm{JW}$ probably resulted from barametric pressure changes during the 7-day period of observation.

\section{Conclusions}

The lack of response in CD-2 may Indicate that the lower portion of this aquifer is not in hydraulic continuity with the upper portion. CD-1 completion zone taps the aquifer above the impervious clay layer (see Figure 8, page 17, Drilling Report). CD-2 completion zone is primarily below the clay layer. (The exact completion zone of $\mathrm{CD}-2$ Includes the clay layer and may or may not tap the upper aquifer. Surveyed elevations for both wells would prove helpful in determining the relationships between the two wells.) Since $C D-2$ water level did not decline during the test, the clay layer at this location may be acting as a hydraulic barrier.

Another explanation may be that the cone of depression did not extend 150 feet from $C D-1$, thus not affecting the water level In CD-2. If this case prevalled, the hydraulic connection between the two zones is unknown. 


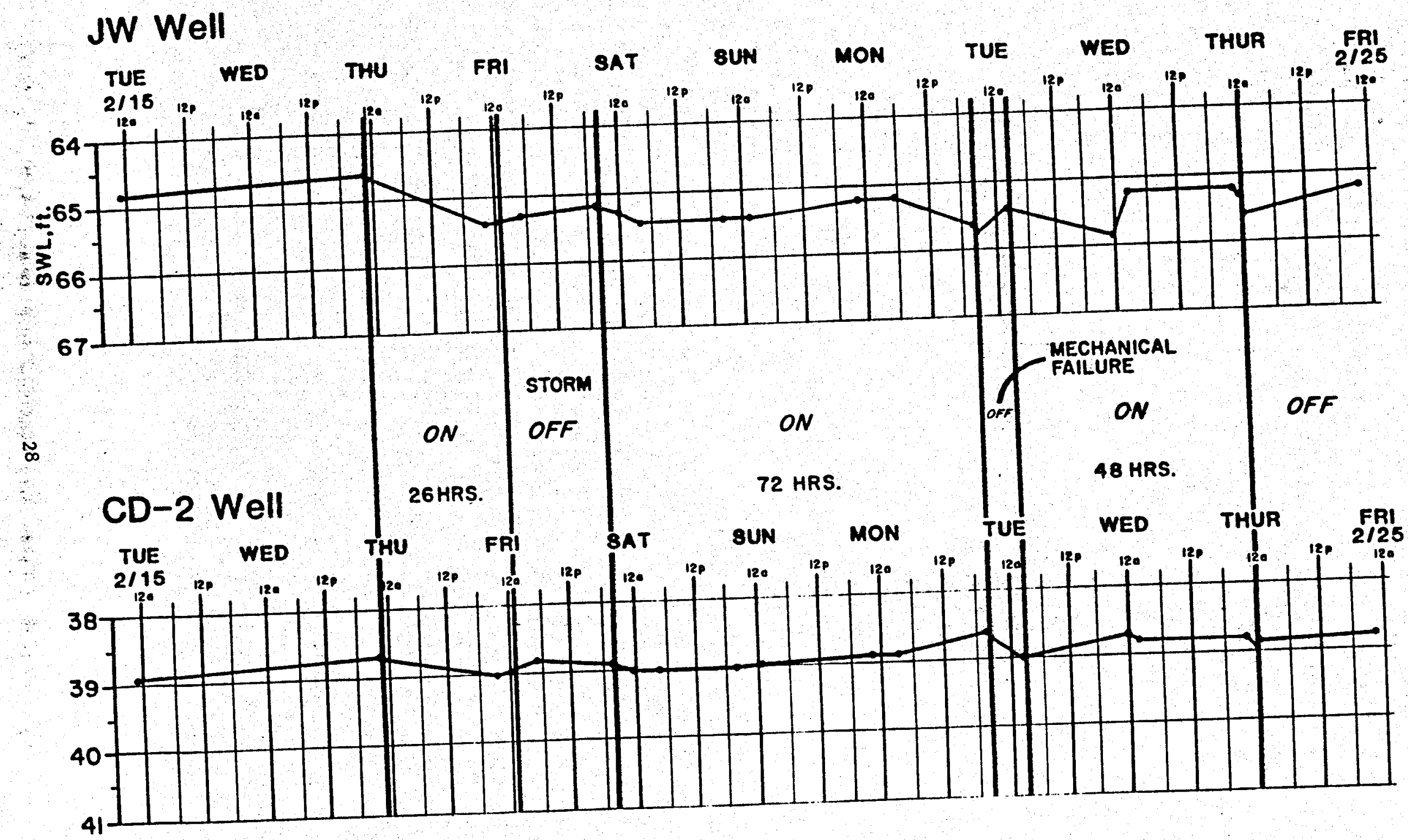

Figure 12: Water Level Measurements in Observation Wells $\mathrm{JW}$ and $\mathrm{CD}-2,2 / 15 / 83$ through $2 / 25 / 83$ 
It is interesting to note that the difference in static water levels between the two wells is only 0.1 feet after correcting for elevation. Such a difference is within the measurement 1imitation of the electric probe and does not tend to support a hydraulic separation of the two zones.

Regardless of hydraulic separation between $C D-1$ and $C D-2$, both wells should be monitored perlodically during production of CD-1. If CD-1 water level drops 30 feet below the static level, $C D-2$ should be monitored as frequently to detect a corresponding change. 


\section{TEMPERATURE GBADIERT MEASUREMENTS IN OBSERVATIOR WELLS}

Measurements of water levels and water temperatures at specific depths were made in observation wells before, during and after pumping We1l CD-1 from February 15 through February 25, 1983. Data from the measurements are graphically Illustrated in Figures 13 and 14. The data show the characteristic temperature-depth profile for Caliente. On February 15, 1983, Well CD-2 had a maximum temperature of nearly $80^{\circ} \mathrm{C}$ $\left(178^{\circ} \mathrm{F}\right)$ at a depth of 60 feet. For Well JW on February 15, a maximum temperature of $80^{\circ} \mathrm{C}$ was measured at 80 feet. The temperature gradient configuration for both wells remained nearly constant during the first five days of pumping Well CD-1. On February 22, a slight Increase in temperature of $1^{\circ}$ to $2^{\circ} \mathrm{C}$ was first recorded in Well $\mathrm{JW}$. Water temperatures continued to increase in JW throughout the well bore. On February 25, a temperature increase of $14^{\circ} \mathrm{C}$ was recorded in JW at a depth of 80 feet. A similar increase in water temperatures throughout the CD-2 well bore was also recorded. A measureable increase was first observed on February 23 , and by February 25 a maximum temperature of $9^{\circ} \mathrm{C}$ was recorded In $C D-2$ at a depth of 80 feet.

The increase in temperature of these two wells is directly related to fluid withdrawal during the sustained pumping of $\mathrm{CD}-1$. The data suggest that the highly transmissive thermal aquifer is in hydraulic continuity with a responsive recharge mechanism that can supply water in excess of $200^{\circ} \mathrm{F}$. The exact location of recharge is unknown, but it appears to be related to the carbonate thrust sheet that strikes north across Antelope Canyon with a near vertical dip. Observation Well JW is located very near this structure. Temperature increases in Observation Well CD-2, which is located nearly 1000 feet east. of the thrust sheet, suggest that another 



\section{JW}

Date 2/15

Time 11:000

S.W.L. 64'II"

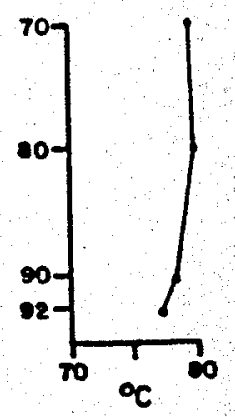

w

\section{Dote $2 / 22$}

Time 10:300

S.W.L. $\quad 65^{\prime} 7^{\prime \prime}$

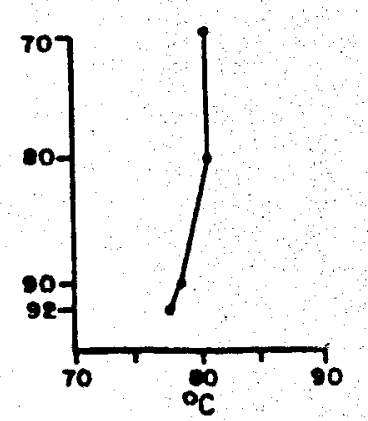

Date 2/17

Time 8:00a

S.W.L. $64^{\prime} 10^{\prime \prime}$
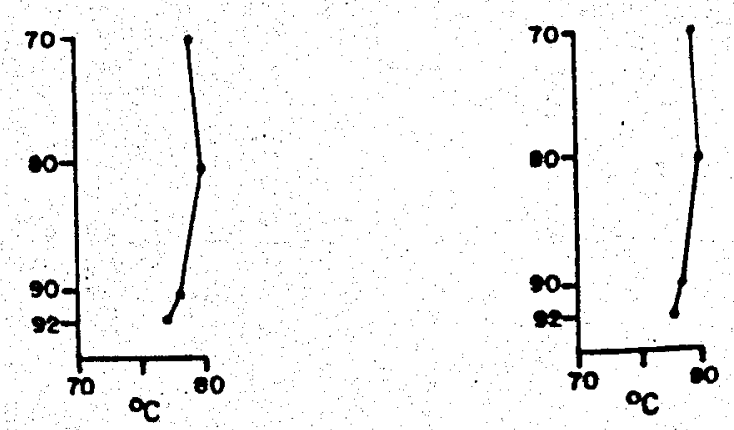

Date $\quad 2 / 18$

Time

S.W.L. $65^{\prime} 4^{\prime \prime}$

Time 2:30p

S.W.L. $65^{\prime} 2^{\prime \prime}$

Date 2/24

Time 9:390

S.W.L. $65^{\prime} 2^{\prime \prime}$

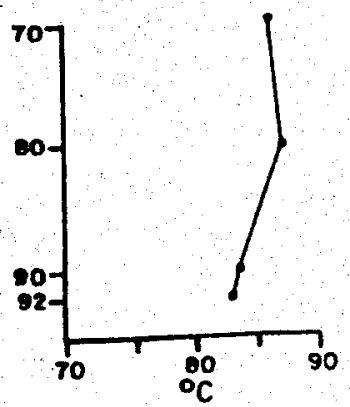

S.W.L. $65^{\prime} 4^{\prime \prime}$

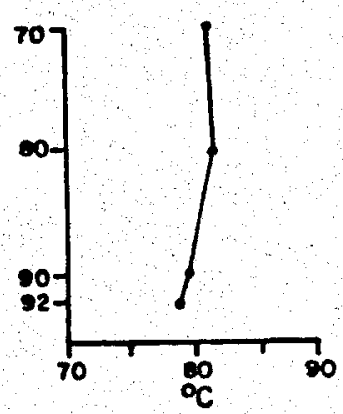

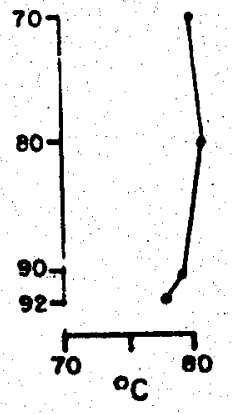

Date 2/24

Time 2:28p

Date $2 / 20$

Time 1:00p

S.W.L. $65^{\prime} 6^{\prime \prime}$

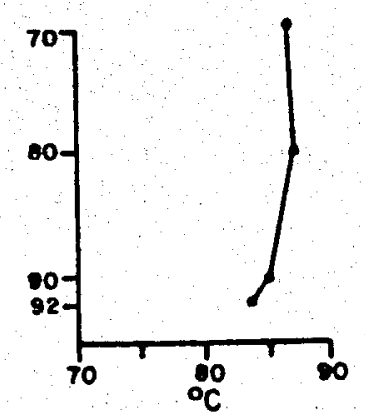

Date 2/21

Time 4:30p

S.W.L. $65^{\prime} 2^{\prime \prime}$

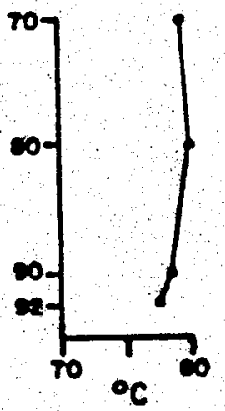

Date $2 / 15,25$

Time 9:40 a

S.W.L. $65^{\prime} 2^{\prime \prime}$

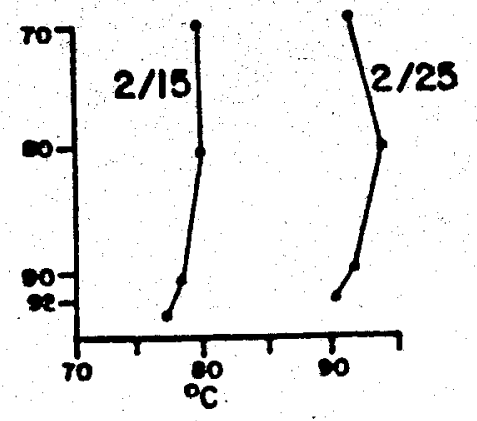

Figure 14: Temperature Gradient Measurements in Observation Well $\mathrm{JW}, 2 / 15 / 83$ through $2 / 25 / 83$ 
structure may also recharge the shallow thermal aquifer with thermal flulds. It is interesting to note that although temperature Increases were observed In both observation wells, no temperature Increase was observed in CD-1. 


\section{FLUID GEOCHEMISTRY}




\section{IHTRODUCTION}

A fluid geochemistry sampling program was completed during the preliminary assessment of geothermal resources in Caliente (Trexler and ochers, 1980a). During that study, 12 fluid samples were collected and analyzed for major, minor and trace elements. Table 1, taken directly from that report, lists the source name, temperature $\left({ }^{\circ} \mathrm{C}\right)$, and chemical composition. The thermal waters range in temperature from 24 to $67^{\circ} \mathrm{C}$ and are chentcally similar to one another. These data are shown graphically in Figure 15. The two chemical groups were differentiated on the basis of chemistry and geography. The large linear shaded area in the center of the diagram (North II) appears to represent a serles of flulds that have formed as a result of mixing of fluid $\| 1$ with flulds 8 and/or 3 .

In addition to major, minor and trace element analyses, fluid samples were also collected and analyzed for deuterium and oxygen-18 - stable light isotopes of hydrogen and oxygen, respectively. Seven samples were collected and the pertinent data are presented in Table 2. The data are also plotted in Figure 16 and the thermal fluids clearly form a separate group. From their position in relation to the meteoric water line, it seems reasonable to assume they are derived from meteoric water precipitated at a higher elevation than local non-thermal fluids and probably recharge from a single source. It is interesting to note that cold waters 9 and 6 form a distinct set. These fluids were collected in the southern portion of the area and display a similar distinct grouping in terms of major and minor dissolved constituents. Sample 7 which lies isotopically between the 9,6 , and thermal groups is chemically simflar and may represent a mixing of these two types of waters. The source of the thermal fluids does not appear to be associated with any local meteoric flulds. 


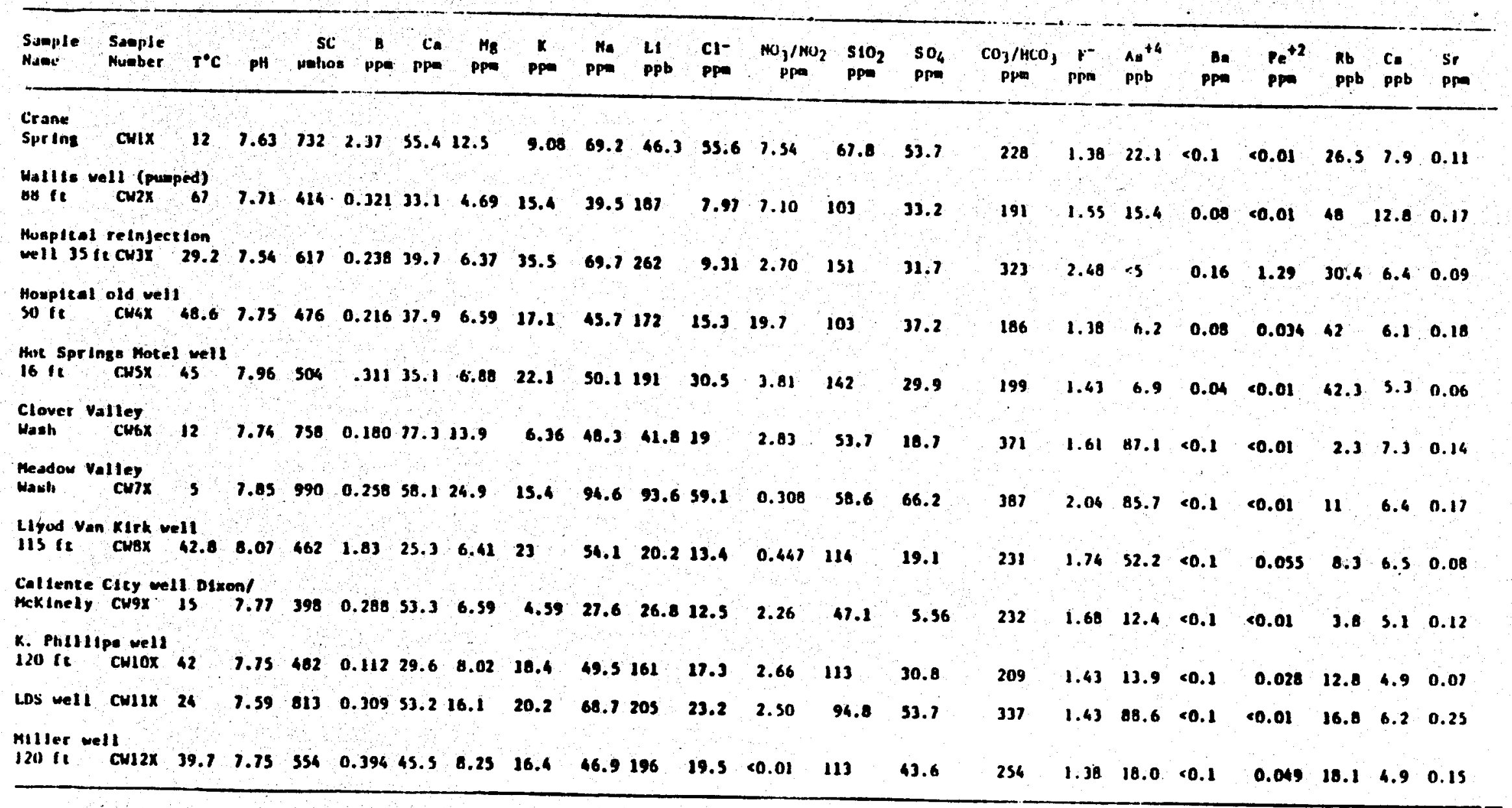

Table 1: Chemical Analyses of Caliente Waters (Trexler and others, 1980a). 


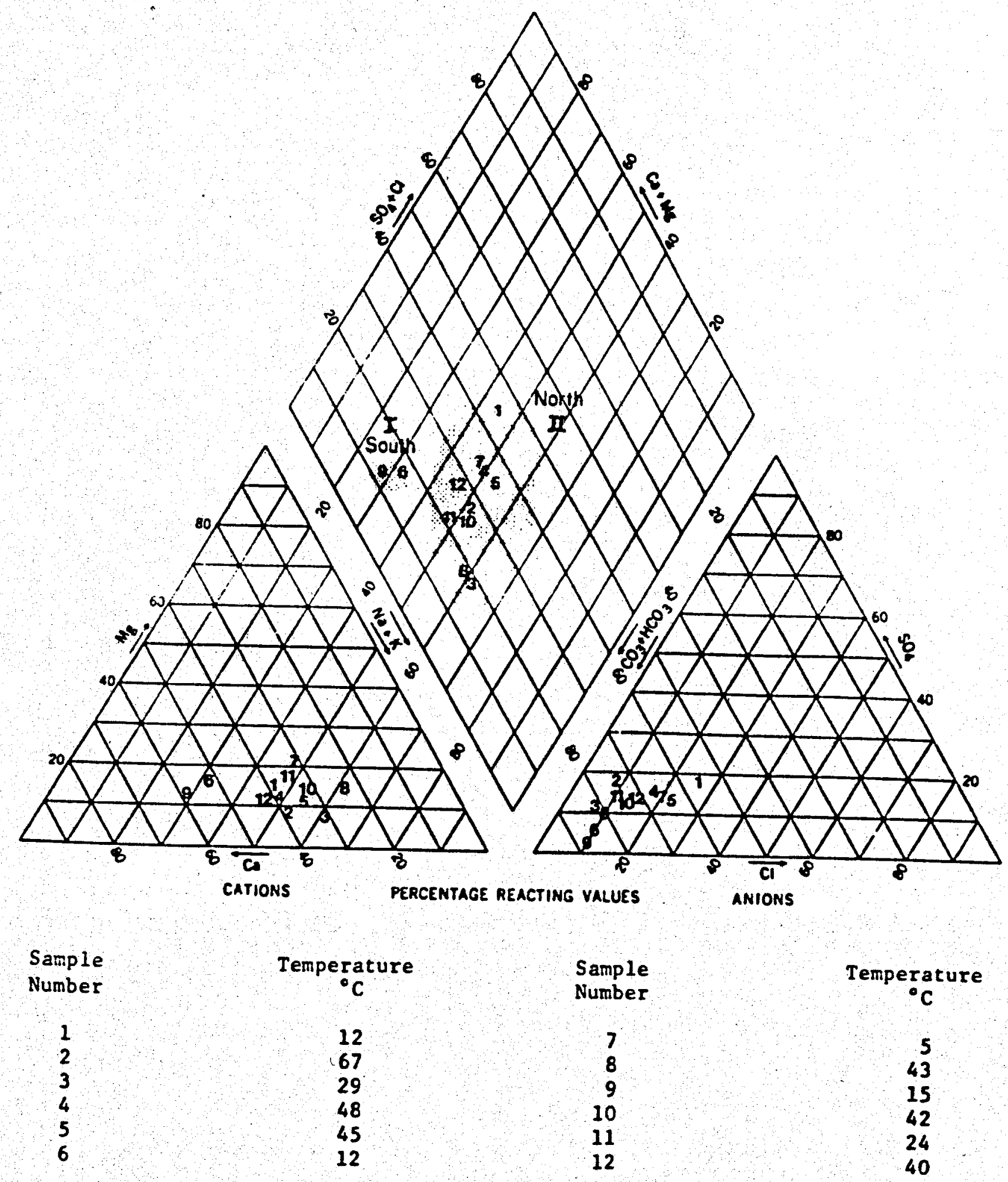

F1gure 15: Plper Plot of Water Samples collected. (Trexler and others, 1980a.) 


\begin{tabular}{|c|c|c|c|c|}
\hline $\begin{array}{l}\text { Sample } \\
\text { Name }\end{array}$ & $\begin{array}{l}\text { Sample } \\
\text { Number }\end{array}$ & $\delta D^{\circ} / 00$ & $\delta^{18} 0^{0} / 00$ & $\mathrm{~T}^{\circ} \mathrm{C}$ \\
\hline Wallis Well. & $\mathrm{CW}-2 \mathrm{~A}$ & -109 & -14.6 & 67.0 \\
\hline $\begin{array}{l}\text { Hospital Rein- } \\
\text { jection Well }\end{array}$ & $C W-3 A$ & -109 & -14.4 & 29.2 \\
\hline $\begin{array}{l}\text { Hot Springs } \\
\text { Motel Well }\end{array}$ & $C W-5 A$ & -106 & -14.3 & 45.0 \\
\hline $\begin{array}{l}\text { Clover Valley } \\
\text { Wash }\end{array}$ & $C W-6 A$ & $-88 /-84$ & -11.7 & 12.0 \\
\hline $\begin{array}{l}\text { Meadow Valley } \\
\text { Wash }\end{array}$ & $C W-7 A$ & -97 & -13.1 & 5.0 \\
\hline Van Kirk Well & $C W-8 A$ & -109 & -14.4 & 42.8 \\
\hline $\begin{array}{l}\text { Caliente City } \\
\text { Well }\end{array}$ & $C W-9 A$ & -84 & -12.1 & 15.0 \\
\hline
\end{tabular}

Values separated by a slash indicate duplicate runs on a single sample.

Table 2: Hydrogen and oxygen stable isotope analyses - Caliente waters (Trexler and others, 1980b). 


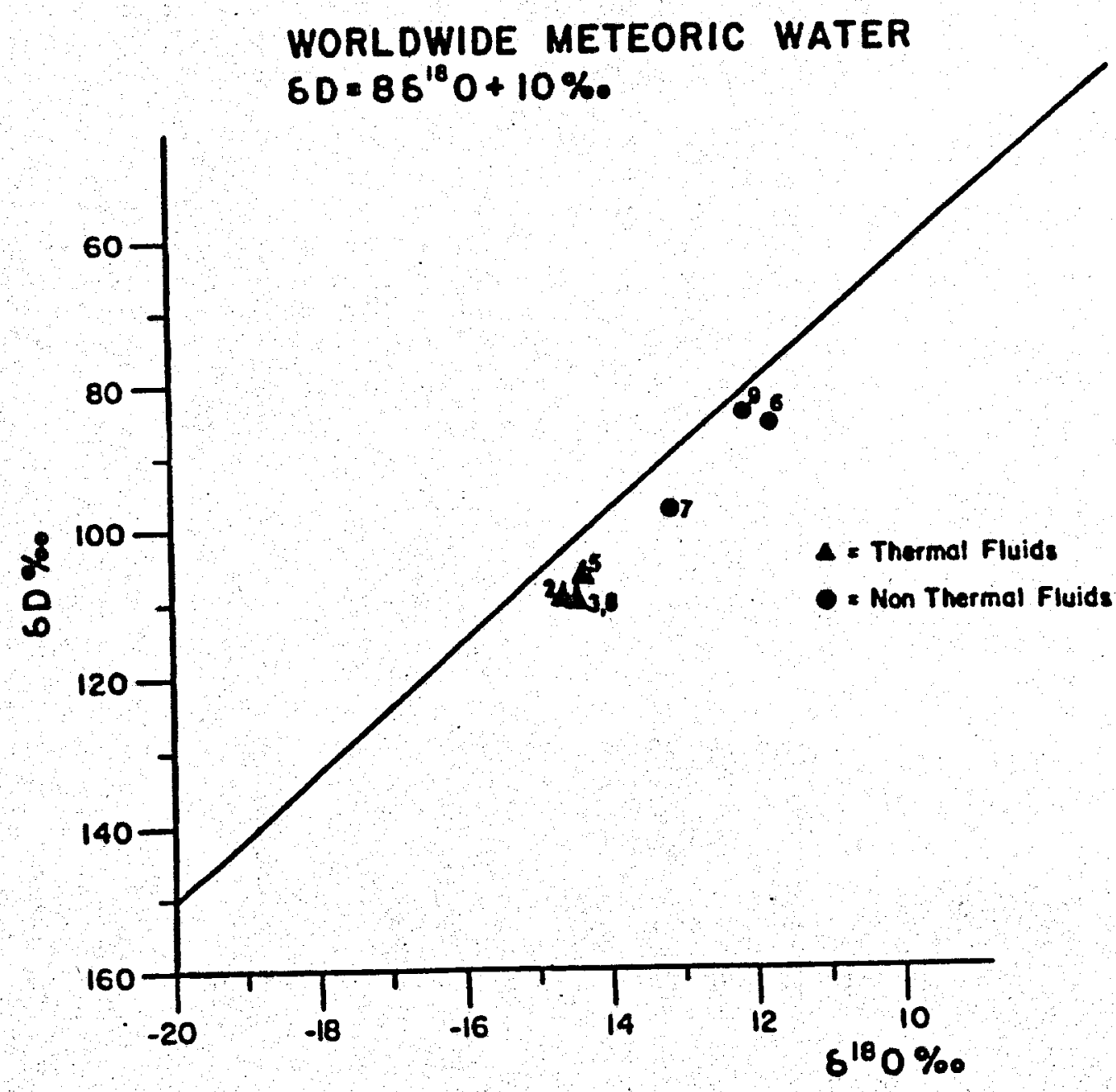

Figure 16: Stable-11ght Isotope ratios of thermal and non-thermal fluids from Caliente. (After Trexler and others, $1980 \mathrm{~b}$; Worldwide Meteoric LIne after Craig, 1963.) 


\section{SAKPLING AND ANALYTICAL TECHNIQUES}

The five fluld samples were collected at irregular intervals over the course of pump testing well CD-1. Samples were collected directly from the discharge plpe which flowed clear, oediment-free water at a constant 255 GPM at $80^{\circ} \mathrm{C}$. Fluid samples were contalned in clean plastic sample bottles that had been rinsed twice with discharging fluids. All the alr was eliminated from the plastic bottle prior to capping. Fluid. samples were not filtered, acidifled, nor diluted in the field. The samples were shipped to a commercial laboratory and analyzed for major dissolved constituents, as well as some minor and trace elements.

Analytical techniques consisted of standard laboratory procedures for analyses of dilute geothermal fluids and included atomic absorbtion, induction coupled plasma, colorametric and hot graphic atomic absorbtion methods.

\section{ANALYTICAI RES ULTS}

The results of the chemical analyses are contained in the Append Ix of this report on data sheets supplied by the laboratory. Fleld data were added after receipt of the laboratory supplied sheets.

The analytical results are in good agreement throughout the sampling period. No large scale physical or chemical variations are observed. The water from CD-1 is sodium-bicarbonate with a total dissolved solid (TDS) of approximately 450 parts per million (PPM). The drinking water for the City of Caliente contains approximately 395 PPM total dissolved solids. A comparison of some of the dissolved constituents in Caliente drinking waters, $C D-1$ geothermal waters, and maximum allowed values for potable water sources (U.S, Public Health Service, 1962) is shown in 
Table 3. It is clear that waters from $\mathrm{CD}-1$ meet and exceed the suggested IImits and, In some cases, exceed values now consumed by the residents of Callente. The flulds are nearly neutral, with respect to acidity, and have a $\mathrm{pH}$ (percent hydrogen lon) of 7.6. The ratlo of measured cations to anions was within five percent for all fluid samples, an Indication that $95 \%$ of the avallable Ionfc constituents in these waters were Identified.

\section{DATA INTERPRETATION}

The major chemical constituents for the five samples collected during pump tests of $C D-1$ do not vary over a wide range and are chemically similar to fluids collected in a previous study (Trexler and others, 1980a). Figure 17 compares the range of values from this study with those collected in 1980. The data points from these analyses are coincident with those from other geothermal waters from Callente.

Temperatures of geothermal waters in Callente range from $67^{\circ} \mathrm{C}$ (Wallis well) to $24^{\circ} \mathrm{C}$ (LDS well). Dilution of thermal waters from Meadow Valley Wash is documented in chemical variations of the fluids as well as fluid temperature. The highest temperatures recorded in callente $\left(95^{\circ} \mathrm{C} ; 204^{\circ} \mathrm{F}\right)$ were measured in well $\mathrm{JW}$, located approximately 600 feet west of $\mathrm{CD}-1$. Although somewhat cooler $\left(80^{\circ} \mathrm{C} ; 176^{\circ} \mathrm{F}\right)$, geothermal fluids from well $\mathrm{CD}-1$ probably represent relatively undlluted geothermal waters. The conclusion drawn in the Trexler and others (1980a) study that thermal flulds originate in or near Antelope Canyon and are quickly cooled and diluted by mixing with waters from Meadow Valley Wash appears to be valid.

Water samples were collected five times during the pump test to ascertain the chemical continulty within the thermal aquifer and to 


\begin{tabular}{|c|c|c|c|}
\hline Element & $\begin{array}{c}\text { (1) LImfts } \\
\mathrm{mg} / 1\end{array}$ & $\begin{array}{l}\text { (2) Callente } \\
\text { Drinking Water }\end{array}$ & $\begin{array}{l}\text { (3) CD-1 } \\
\text { Geothermal Water }\end{array}$ \\
\hline Arsenic (As) & 0.05 & .0124 & .0146 \\
\hline Barium (Ba) & 1.0 & $<0.01$ & .088 \\
\hline Fluoride (F) & 1.5 & 1.68 & 1.48 \\
\hline Manganese (Mn) & 0.05 & - & $<.01$ \\
\hline Sodfum (Na) & 200 & 27.6 & 39.3 \\
\hline Calcium (Ca) & 200 & 53.3 & 32.12 \\
\hline Magnesium (Mg) & 125 & 6.59 & 5.2 \\
\hline Bicarbonate $\left(\mathrm{HCO}_{3}\right)$ & 500 & 232 & 215 \\
\hline Chloride (C1) & 250 & 12.5 & 4.6 \\
\hline Sulfate $\left(\mathrm{SO}_{4}\right)$ & 250 & 5.56 & 15.1 \\
\hline Nitrate $\left(\mathrm{NO}_{3}\right)$ & 45 & 2.26 & 11.0 \\
\hline Boron (B) & 20 & .288 & 0.04 \\
\hline TDS & 1000 & 395 & 445 \\
\hline
\end{tabular}

(DATA SOURCES)

(1) U.S. Public Health Service, 1962 (after Matthess, 1982, PP. 338).

(2) Trexler and others, $1980 \mathrm{a}$.

(3) This study, average of 5 analyses.

Table 3: Comparison of Callente drinking waters, CD-1 geothermal waters, and U.S. Public Health Service standards for limiting values of dissolved constituents for potable waters. 


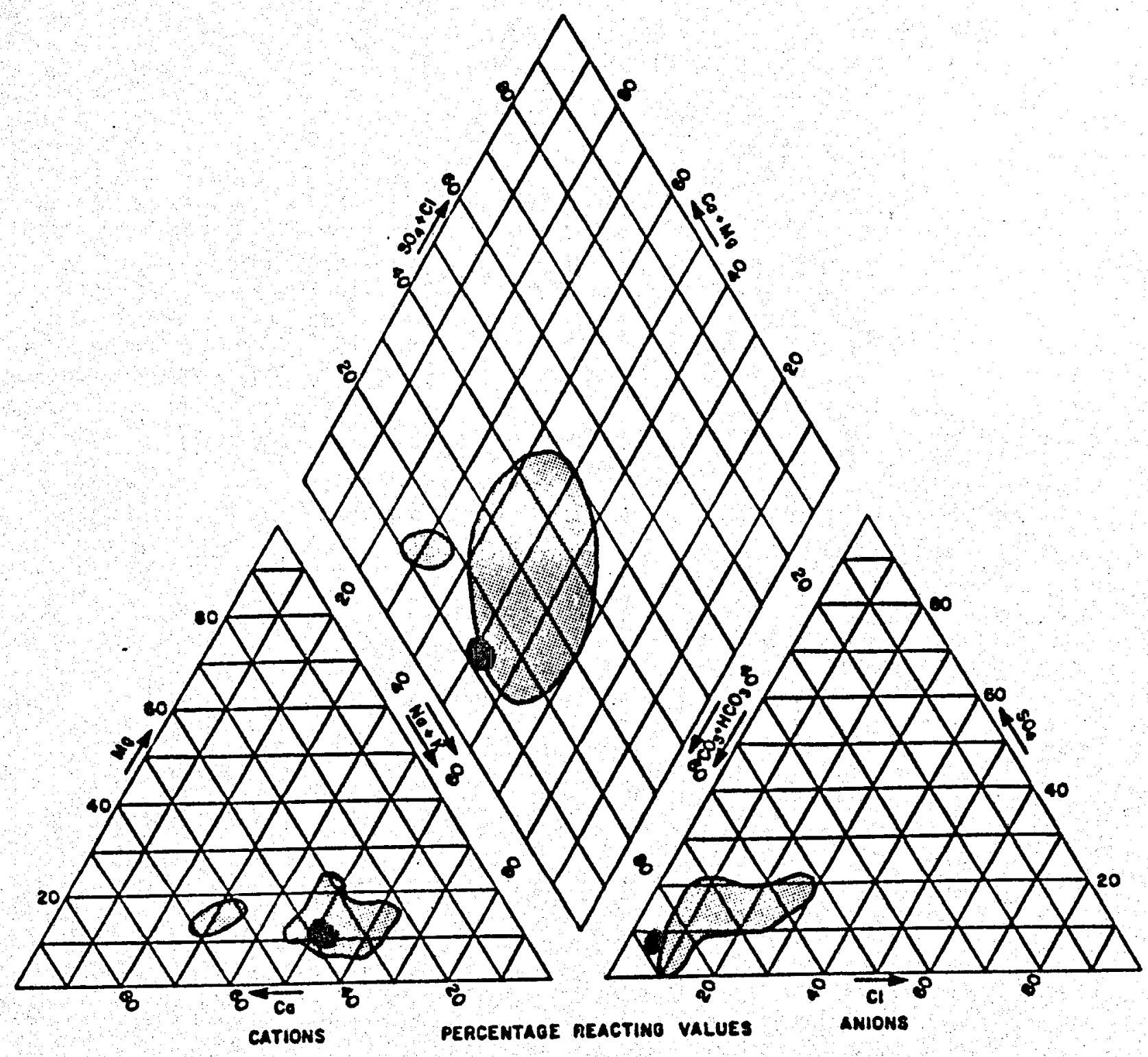

Figure 17: Piper plot comparative analysis of thermal waters collected during pump test of $C D-1$ geothermal well (dark areas). (Shaded areas after Trexler and others, 1980a.) 
Identify possible contamination of the aquifer from a non-thermal source. Figure 18 shows the variation concentrations of the major dissolved constituents from February 17, through February 24, 1983. For the cations (Sodium, Na; Calclum, Ca; Potasstum, $K_{;}$and Magneslum, Mg), no significant variation in concentration is observed. These data suggest that the thermal aquifer that produced these fluids 18 chemically homogeneous.

For the anions (BIcarbonate, $\mathrm{HCO}_{3}$; Sulfate, $\mathrm{SO}_{4} ; \mathrm{Nitrate,} \mathrm{NO}_{3}$; and Chloride, $\mathrm{Cl})$, some varlations can be seen. The drop in Bicarbonate $\left(\mathrm{HCO}_{3}\right)$ may indicate a reduction in the amount of dilution by meteoric waters, which have higher Bicarbonate concentrations than thermal fluids. No significant temperature Increase was not iced in well CD-1, but temperature Increases of several degrees centigrade were recorded in two adjacent observation wells. Sulfate $\left(\mathrm{SO}_{4}\right)$ also shows a slight drop for the third sample with recovery in samples 4 and 5. The reason for this 18 not clear and it may simply represent a sampling or analytical error. Nitrate $\left(\mathrm{NO}_{3}\right)$ concentrations show a sharp increase between samples 2 and 3 . This significant increase (from 5 to 18 PPM in 48 hours) followed by a gradual decline, almost certainly indicates a source of contamination. Major sources of Nitrate include large-scale fertilization, rain run-off from IIvestock and feedstock corrals, and sewage disposal areas (Hem, 1970). These may represent sources of Nitrate contamination in areas adjacent to Antelope Canyon, but these activities have not been documented within Antelope Canyon. A fourth possibility may be contamination from water standing in a stagnant well bore. Well JW, located approximately 600 feet west of $C D-1$ was never pumped. Significant amounts of Nitrate may have accumulated in the stagnant water standing in the well bore. The shape of the "curve" for Nitrate in Figure 4 is approximately the same as those 


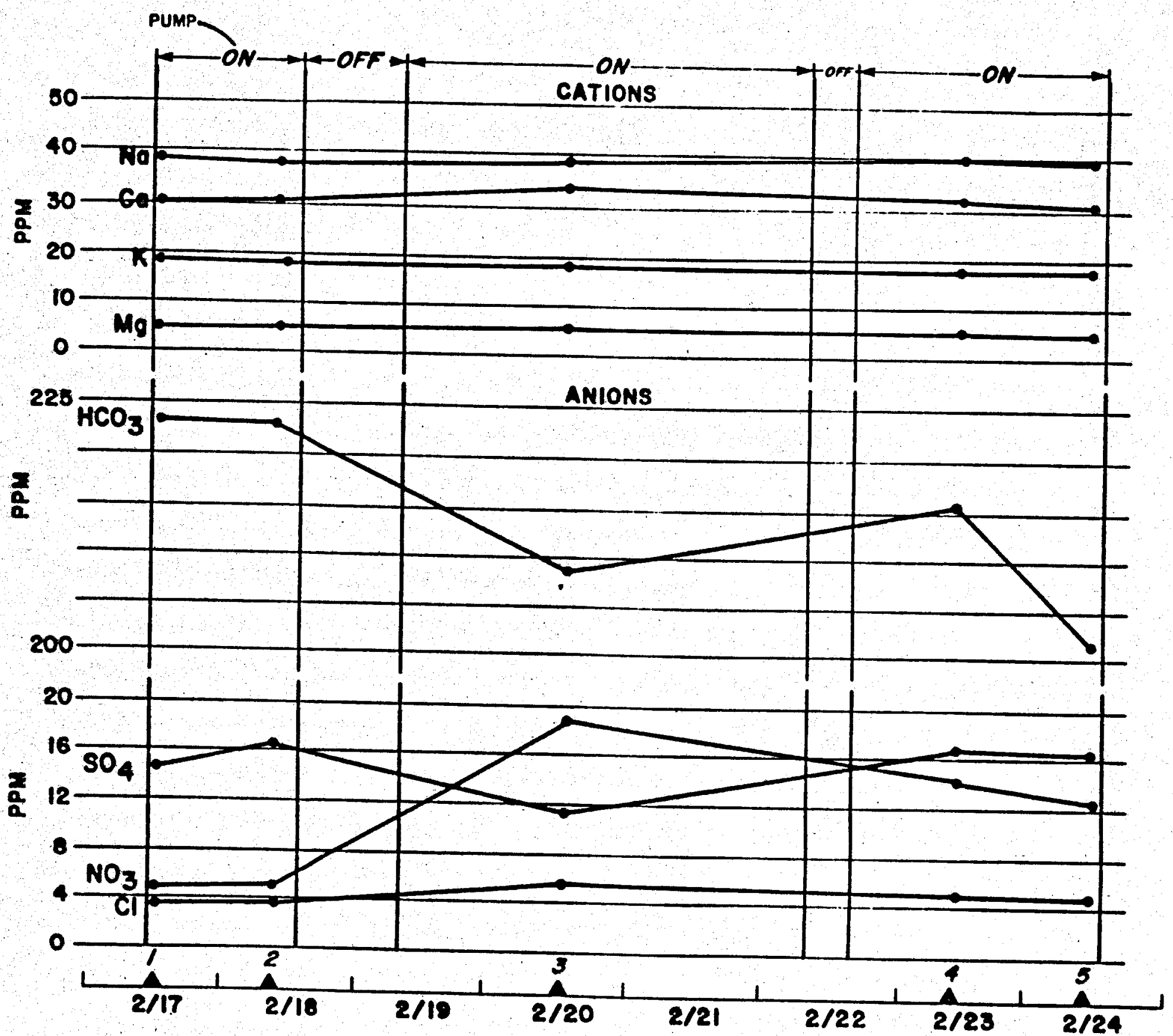

$\Delta=$ sample fime, number

Figure 18: Varlations in chemical composition of fluids sampled during pump tests of $\mathrm{CD}-1$ geothermal well. 
seen in slug-type tracer tests which are used to demonstrate transmissivity between adjacent weils in a limited area. The well bore JW may In fact be the Nitrate source. On the other hand, assuming 60 hours of pumping prior to the Increase in Nitrate concentration, those fluids would have to travel approximately 600 feet in 60 hours, 10 feet per hour, or two Inches per minute. Even in this highly transmissive aquifer, two inches per minute seems fast. A fifth explanation is sampling and analytical error. Concentrations of Chloride (C1), the fourth major anion, remained the same throughout pumping.

Chemical geothermometers were calculated from Silica $\left(\mathrm{SIO}_{2}\right)$ values for samples 1 and 5. These geothermometers are based on chemical equilibria equations and are based on, among other things, the concept that no mixing occurs with non-thermal fluids. Since mixing in these waters is almost certain, these data are listed largely for academic reasons. The data are presented in the table below and two facts should be remembered: The maximum temperature recorded in $\mathrm{CD}-1$ is $80^{\circ} \mathrm{C}\left(176^{\circ} \mathrm{F}\right)$; the maximum temperature recorded in Antelope Canyon (JW we11) was $95^{\circ} \mathrm{C}\left(204^{\circ} \mathrm{F}\right)$.

\begin{tabular}{|c|c|c|c|c|c|c|c|c|}
\hline SAMPLE & ${ }^{\circ} \mathrm{C}$ & ${ }^{\circ} \mathrm{F}$ & ${ }^{\circ} \mathrm{C}$ & ${ }^{{ }^{F}}$ & ${ }^{\circ} \mathrm{C}$ & ${ }^{{ }^{F}}$ & ${ }^{\circ} \mathrm{C}$ & ${ }^{\circ} \mathrm{F}$ \\
\hline$C D-1$ & 141 & 286 & 136 & 277 & 115 & 239 & 100 & 212 \\
\hline $\mathrm{CD}-2$ & 142 & 288 & 137 & 279 & 116 & 241 & 98 & 208 \\
\hline
\end{tabular}

*A. Quartz, no steam loss

B. Quartz, maximum steam loss

C. Chalcedony

D. $\mathrm{Na}-\mathrm{K}-\mathrm{Ca}$ 
The Silica geothermometers ( $A, B, C$ ) suggest that the ultimate reservoir temperatures may range from $115^{\circ} \mathrm{C}\left(239^{\circ} \mathrm{F}\right)$ to $142^{\circ} \mathrm{C}\left(288^{\circ} \mathrm{F}\right)$.

The cation geothermometer (E) shows data more consistant with the highest temperatures measured in Antelope Canyon. 


\section{CONCLUSTOHS AND RECONERDATIONS}

Direct use of geothermal fluids for district space heating has been hampered In several areas by a combination of technical and economic barriers. Technical considerations include insufficient temperature, poor flow rate, unsatisfactory water quality, and large depth-to-resource. Economic considerations are factored into each technical aspect, but are much more significant during resource development. The choice of hardware for the pumping and distribution system, the method of fluid disposal or reinjection, labor costs, and charges assoclated with financing represent critical decision points in the development of a geothermal resource.

This report provides a detailed description of a geothermal resource that presents no known technical barriers to development. The two test wells are located within a mile of downtown Callente. The temperature of the pumped fluids was $80^{\circ} \mathrm{C}\left(176^{\circ} \mathrm{F}\right)$, but temperatures as high as $96^{\circ} \mathrm{C}$ $\left(204^{\circ} \mathrm{F}\right)$ were measured in a well 600 feet west of $\mathrm{CD}-1$. The depth to the resource is 100 feet and the aquifer transmissivity is extremely high. In addition, the water quality is excellent and can be used for both space heating and domestic (potable) applications.

An engineering and economic feasibility study completed for the City of Callente by the Oregon Institute of Technology, GEO-HEAT Center estimated that a city-wide geothermal space heating district could be developed and installed for approximately $\$ 2.5 \mathrm{mill}$ lon. $V$ This study assumed a resource temperature of $160^{\circ} \mathrm{F}$ and a flow rate of $850 \mathrm{GPM}$. Because the resource temperature is higher than expected, a flow rate of only 750 GPM is required.

The test results from this study strongly suggest that the resource can support the proposed geothermal space heating district. Future testing should Include a larger well and pump and a sustained 30 day pump test at 
700 to 1000 GPM. Chemfical analyses on pumped flulds, and water level and temperature gradient measurements on the surrounding observation wells are also recommended.

Finally, the results of this program are positive and encouraging, and will be extremely helpful in the subsequent development in the city of Caliente. 


\section{RBPEREYCES}

Craig, H., 1963, The 1sotoplc geochemistry of water and carbon in geothermal areas: Proc. Sploeto Conference on Nuclear Geology, Tonglorgi, ed., p. 17-53.

District Heating System, C1ty of Caliente, Nevada, 1980: GEO-HEAT Utilization Center, Oregon Institute of Technology, Klamath Falls, Oregon.

Hem, John D., 1970, Study and interpretation of the chemfcal characteristics of natural water: U.S. Geol. Survey Water-Supply Paper 1473, 363 p.

Matthess, Georg, 1982, The properties of groundwater: New York, John Wiley and Sons, 406 p.

Trexler, D.T., Flynn, T., Koenlg, B.A., and Bruce, J., 1980a, Assessment of geothermal resources of Callente, Nevada: Nevada Bureau of Mines and Geology. Work performed for U.S. Dept. of Energy under contract no. DE-AC08-79NV10039.

Trexler, D.T., Koenlg, B.A., Flynn, T., and Bruce, J.L., 1980b, Assessment of the geothermal resources of Carson-Eagle Valleys and Big Smoky Valley, Nevada: First Annual Report, DOE/NV/10039-2.

Tschanz, C.M., and Pampeyan, E.H., 1970, Geology and mineral deposits of Lincoln County, Nevada: Nevada Bureau of Mines and Geology Bullet in 73. 


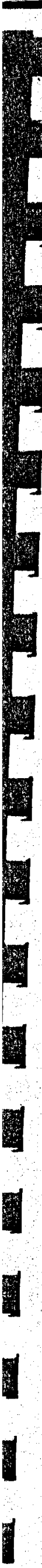

PLATES

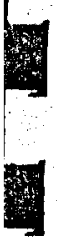

8

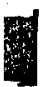

$=$

.

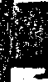

d 


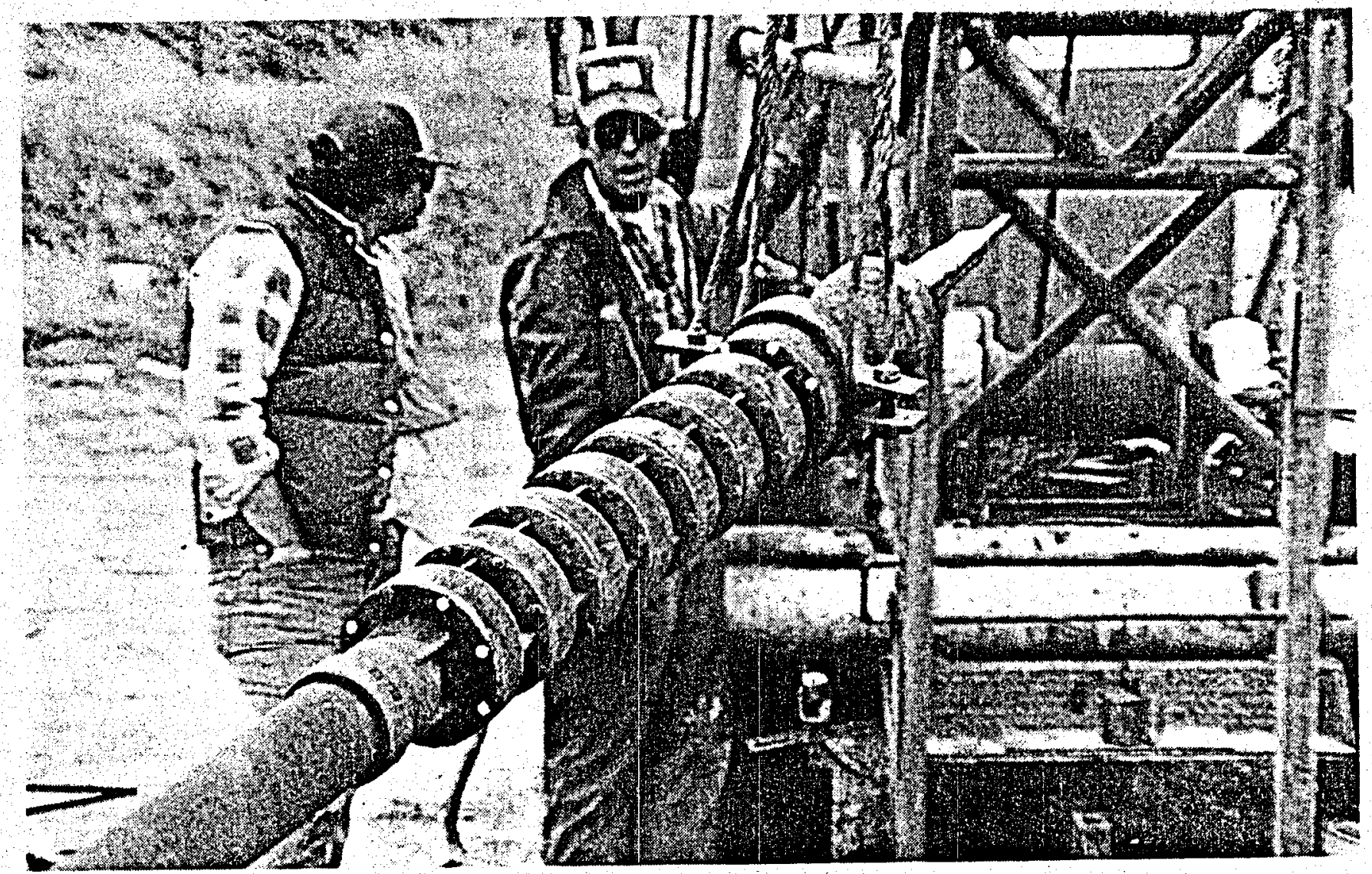

Plate 1: Line-shaft pump with $10 \mathrm{ft}$. sucker tube.

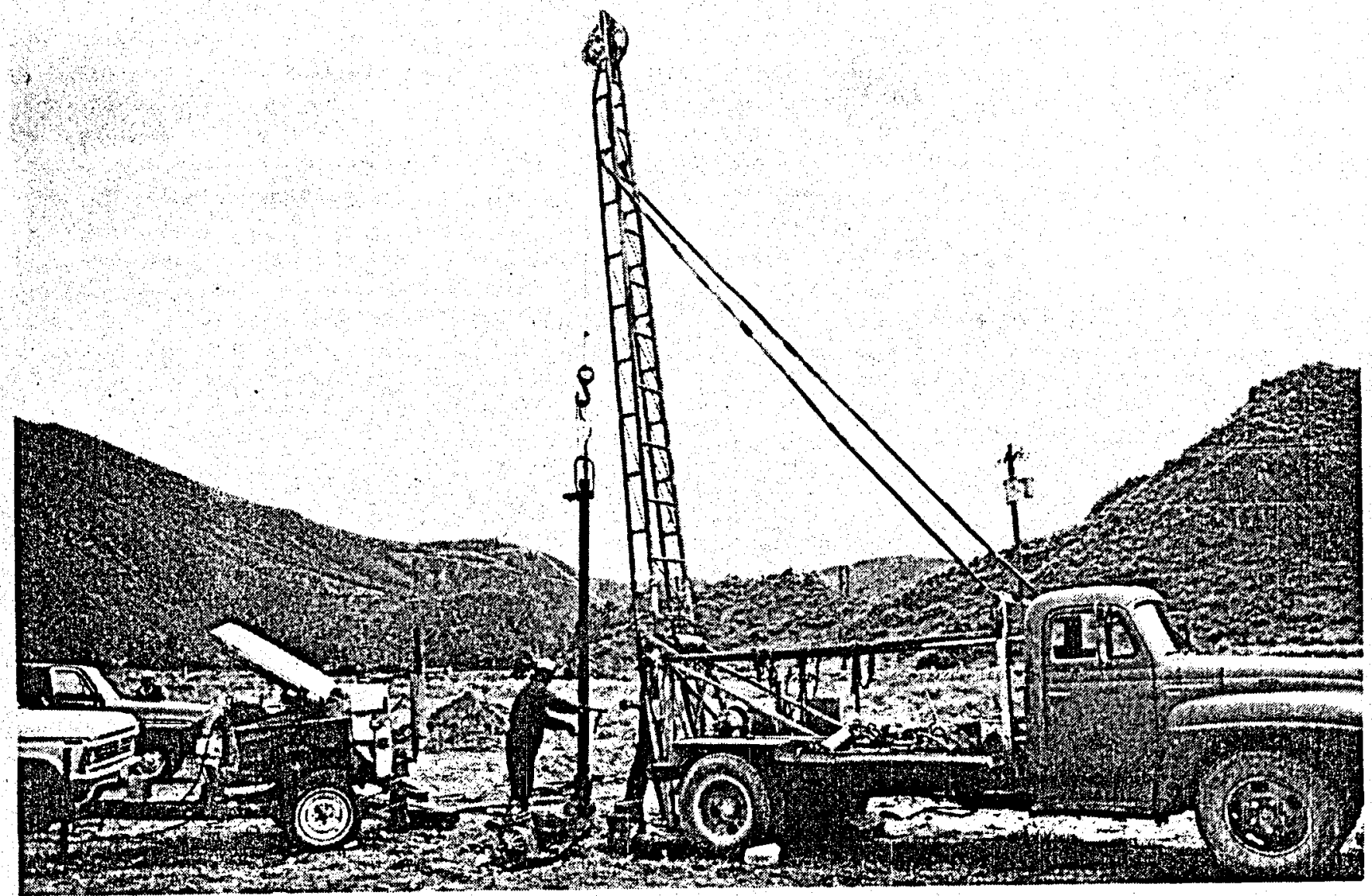

Plate 2: Installing pump in well CD-1. 


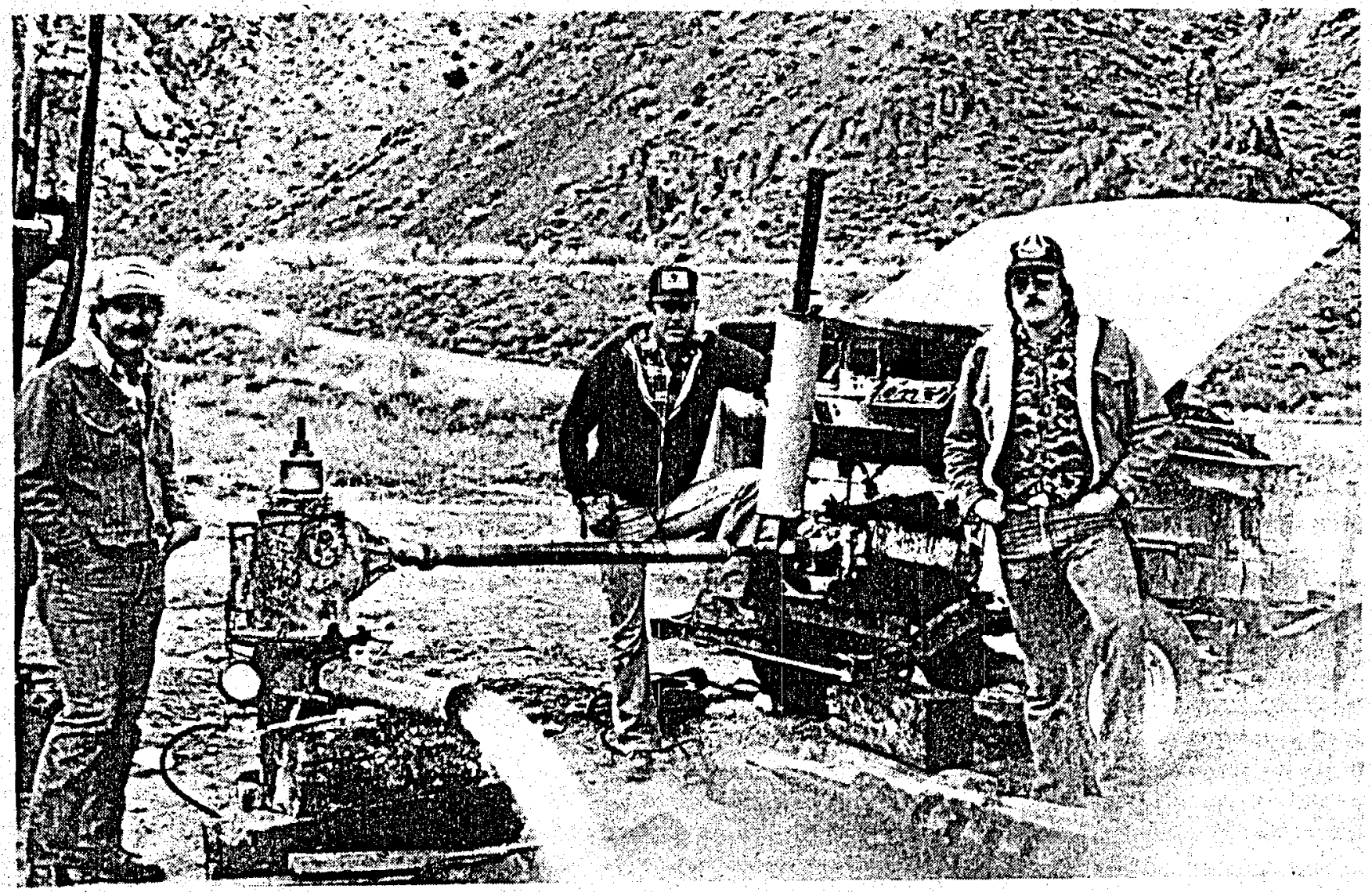

Plate 3: Flow-testing CD-1 with varlable speed motor.

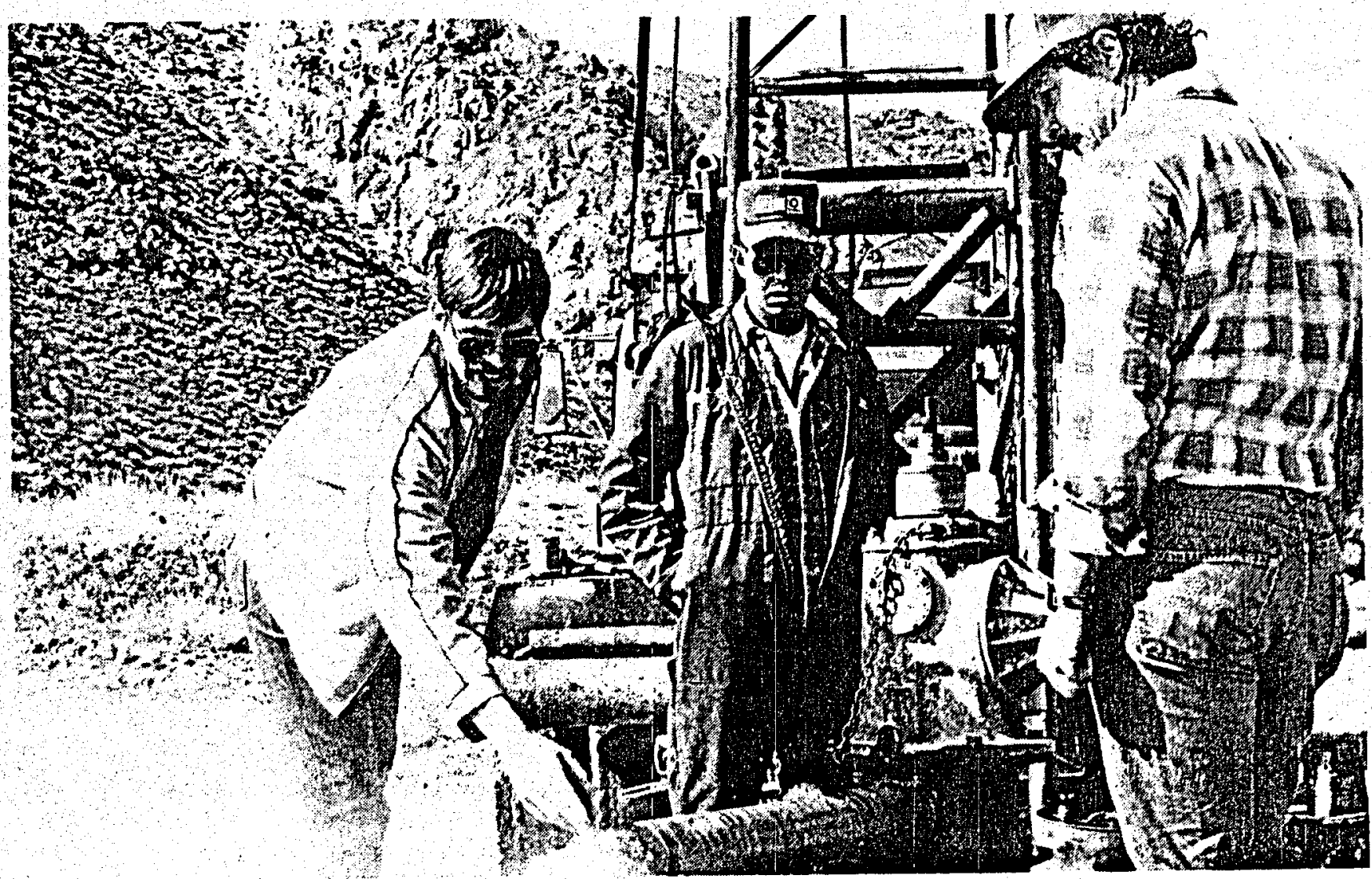

Plate 4: Temperature and discharge measuring technique, $C D-1$. 


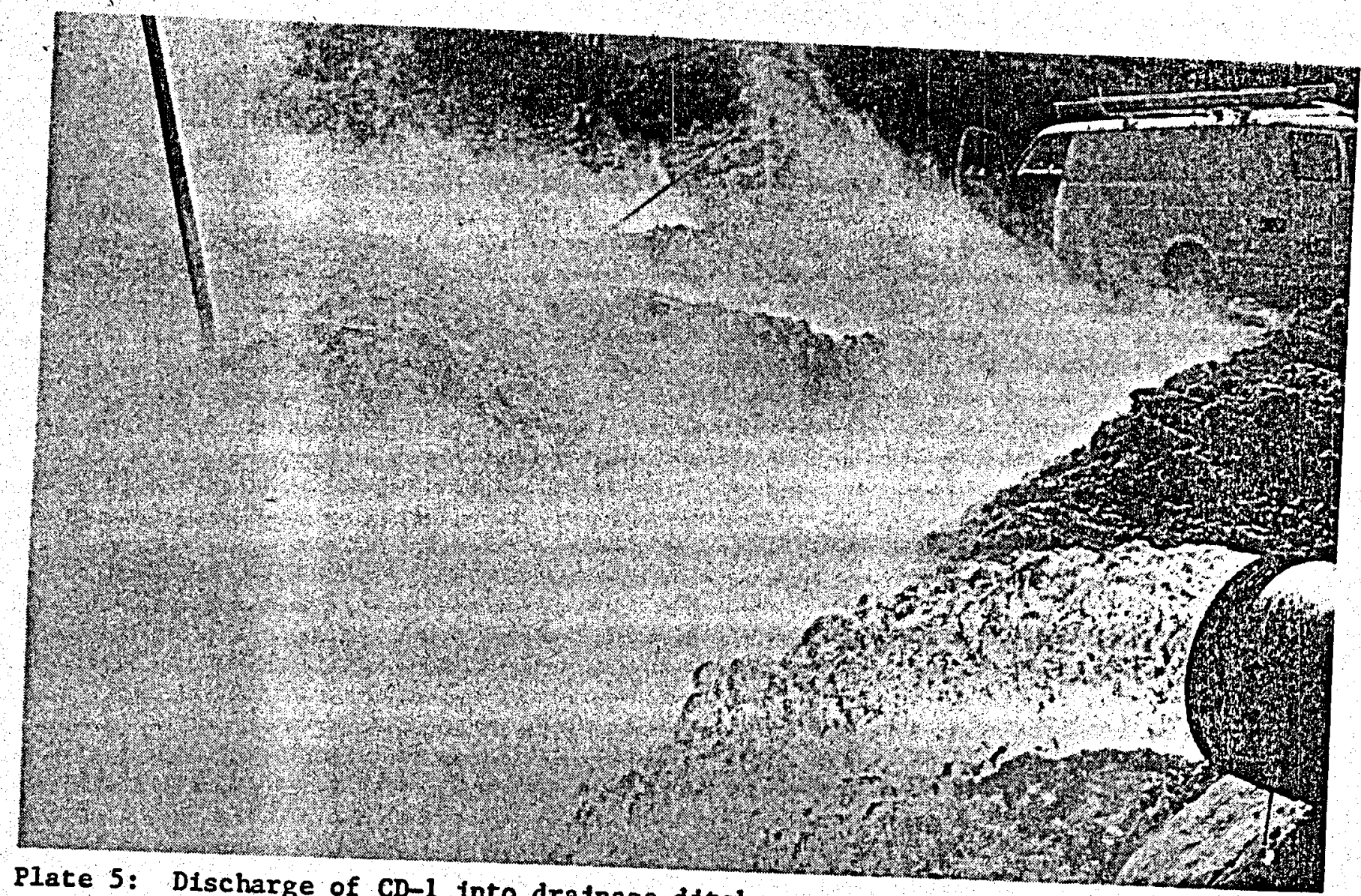

Plate 5: Discharge of CD-1 into drainage ditch.
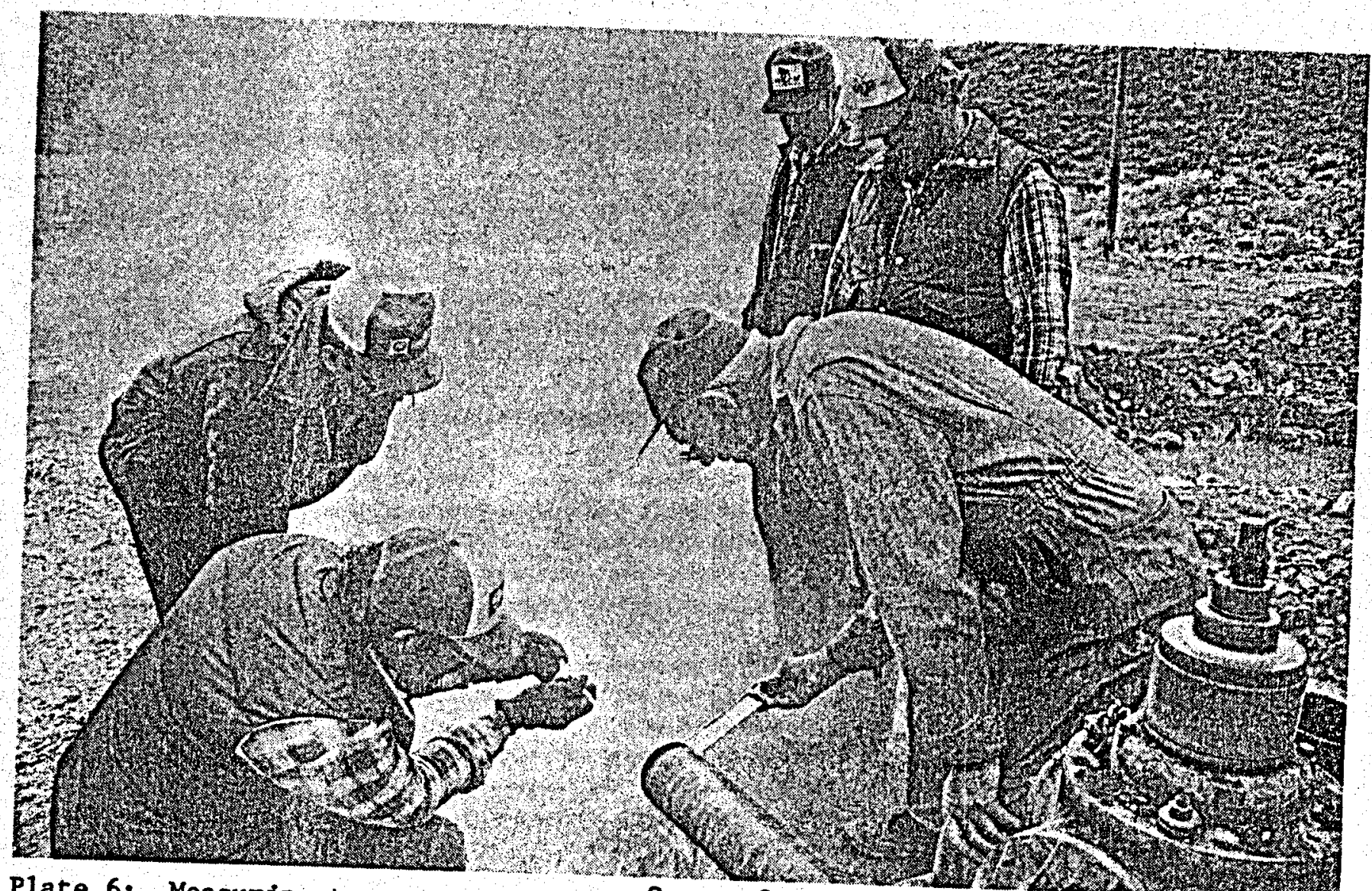

Plate 6: Measuring temperature $\mathrm{CD}-1,80^{\circ} \mathrm{C}, 178^{\circ} \mathrm{F}$. 


\section{APPENDIX}

CHEMICAL ANALYTICAL DATA AND FIELD DATA FOR WATER SAMPLES COLLECTED DURING PUMP TESTS OF CD-1, GEOTHERMAL WELL, CALIENTE, NEVADA 


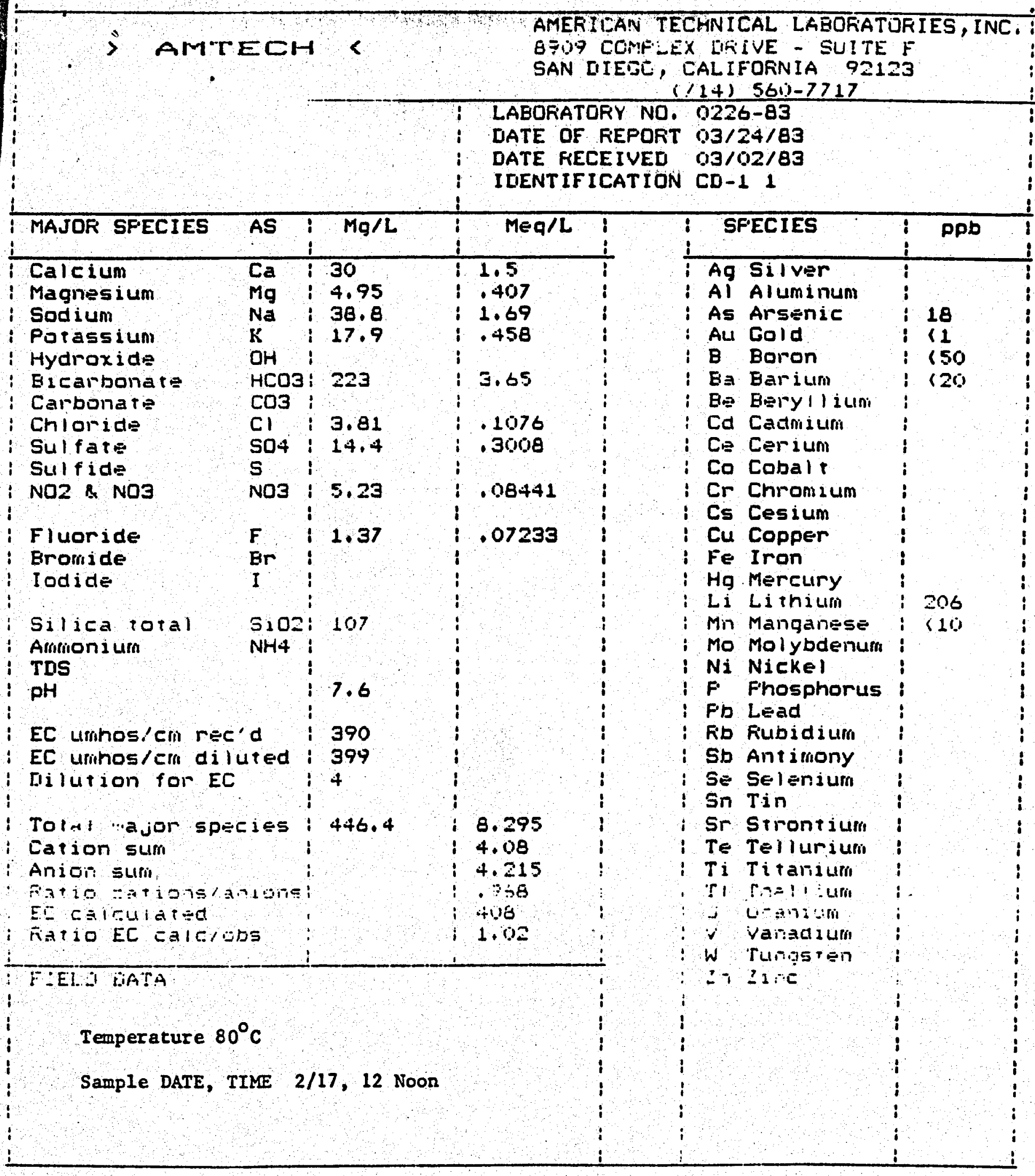




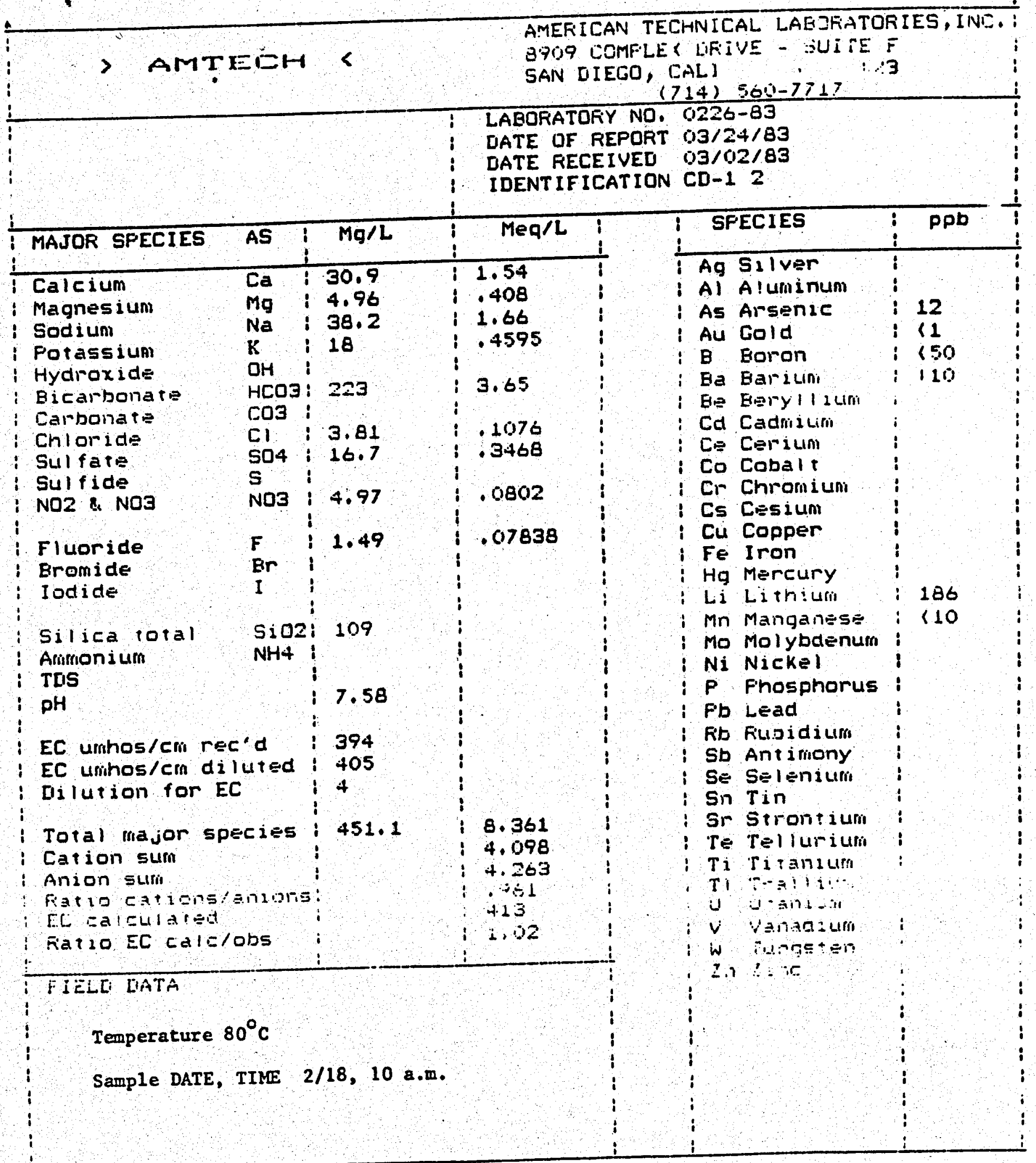




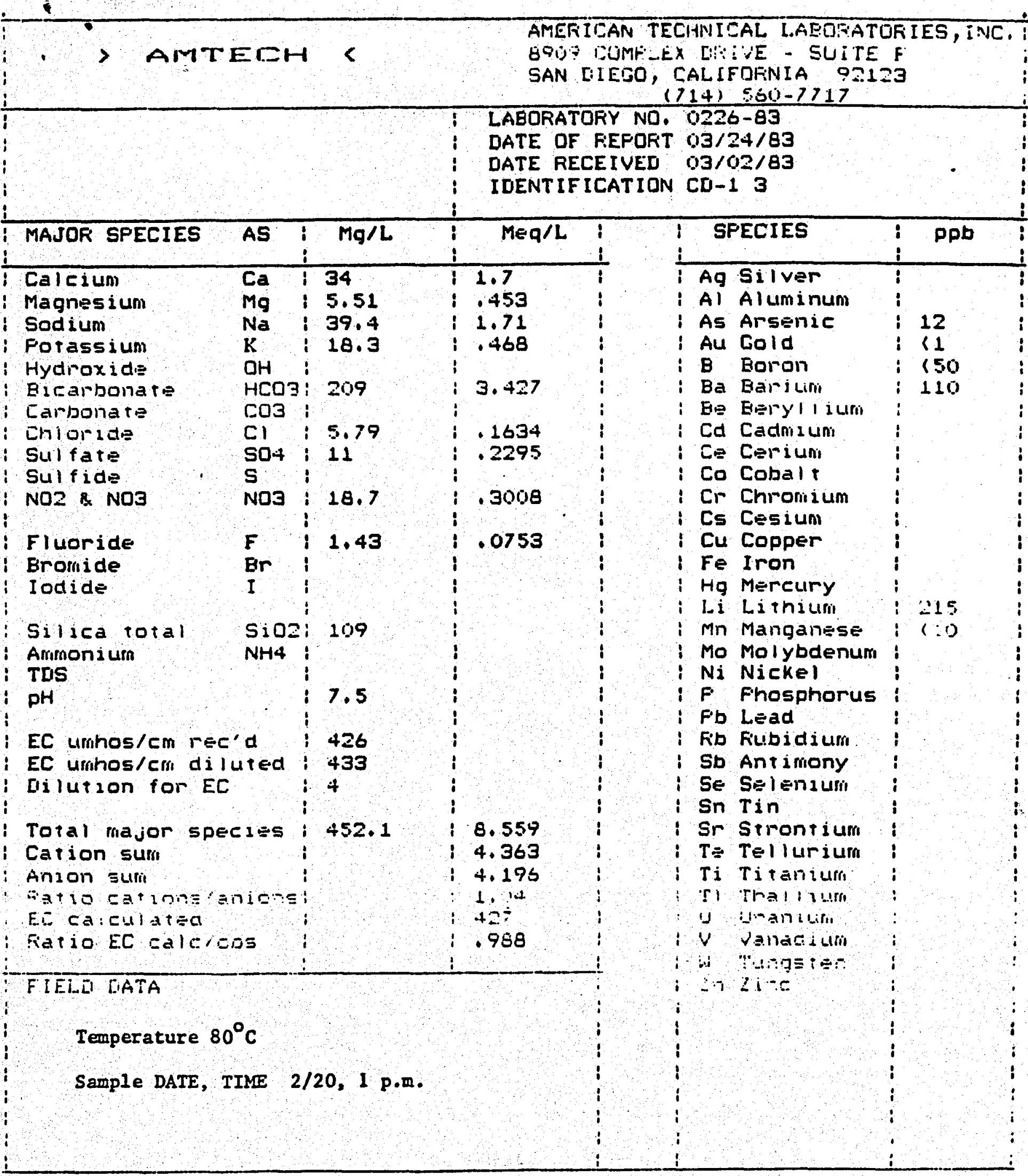




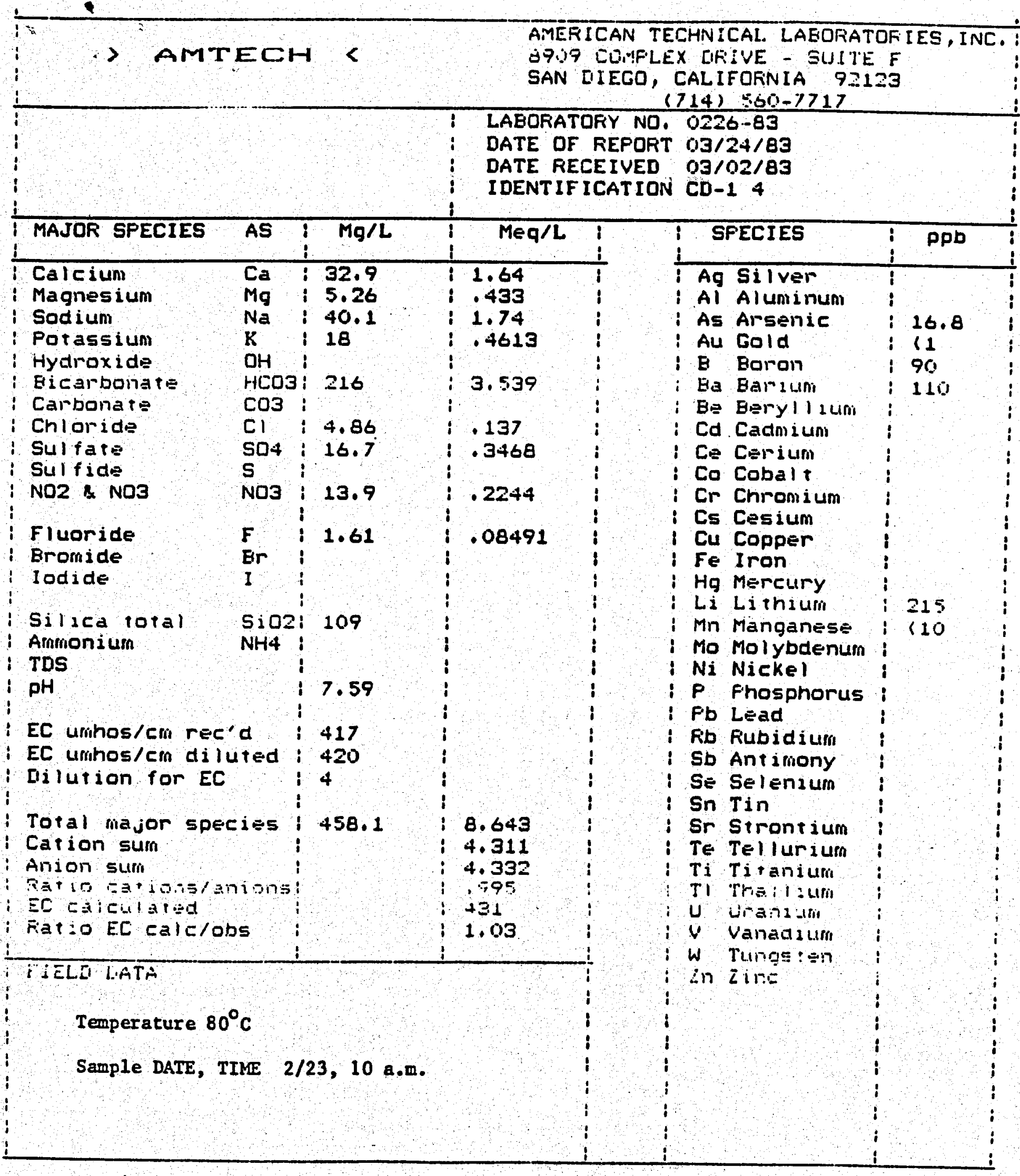




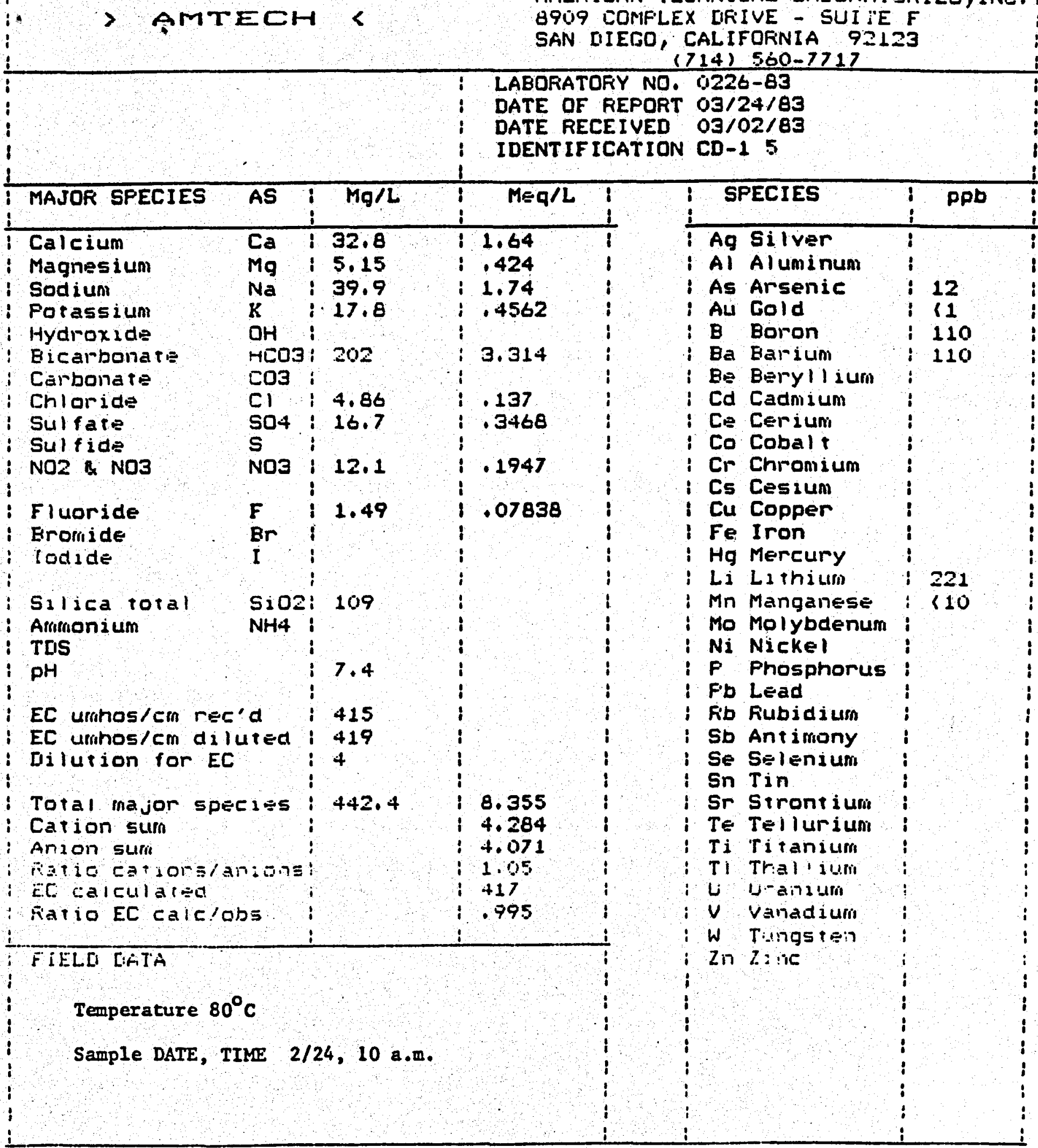

